\title{
A Pheromone-Degrading Aldehyde Oxidase in the Antennae of the Moth Manduca sexta
}

\author{
Robert Rybczynski, Jeffrey Reagan, and Michael R. Lerner \\ Section of Molecular Neurobiology and Howard Hughes Medical Institute, Yale School of Medicine, New Haven, \\ Connecticut 06510
}

\begin{abstract}
Antennae of the tobacco hornworm moths Manduca sexta contain an aldehyde oxidase (AOX) that oxIdlzes aldehydes to carboxylic acids. The enzyme, which is distinguishable trom aldehyde-oxidizing activities in other tissues, is secreted into the receptor lymph that bathes the primary olfactory dendrites. First detectable about $3 \mathrm{~d}$ before eclosion, AOX levels increase through the first day after eclosion. This parallels the development of the antennal responsiveness to bombykal (a male attractant aldehydic pheromone produced by female $M$. sexta) and trans-2-hexenal (an aldehyde commonly found in leaves). The AOX is about $60 \%$ more abundant in antennae of males than in antennae of females.

The antennal AOX is a dimer with $M$, of $295 \mathrm{kDa}$ and is capable of oxidizing a variety of aldehydes. Of all aldehydes examined, the pheromone bombykal was the best substrate with an apparent $K_{m}$ of $5 \mu \mathrm{M}$, whereas the next best substrate, benzaldehyde, had an apparent $K_{m}$ of $255 \mu \mathrm{M}$. Using kinetic parameters estimated in vitro and the assumption of firstorder kinetics, the half-life of bombykal in sensilla was estimated to be about $0.6 \mathrm{msec}$. The affinity of the antennal AOX for bombykal, its location in the receptor lymph, and its pattern of developmental expression all suggest that it plays a role in modulating the sensitivity of adult $M$. sexta to aldehyde odors and, in particular, the sensitivity of males to the pheromone bombykal.
\end{abstract}

A sensitive olfactory system requires more than just odor receptors and transductory molecules. For instance, processes which control the half-life of a given odor in the perireceptor space will have a strong influence on the sensitivity of receptor neurons for that odor and the length of the neuronal response. At least 3 pathways, which could act separately or in concert, can control the probability that an odorant will bind one or more times to an olfactory receptor (Getchell et al., 1984). One, an odorant may diffuse or be actively transported back to the external environment. Two, an odorant may be internalized by olfactory neurons or neighboring cells. Three, an odor may be enzymatically altered to an inactive or a poorly active form. In

\footnotetext{
Received June 24, 1988; revised Aug. 30, 1988; accepted Sept. 7, 1988.

We thank A. Roby for help throughout, Drs. S. Edelstein and R. G. Vogt for their comments on the manuscript, and M. Goulet, L. Kiessling, and T. Sammakia (Department of Chemistry, Yale University) for performing the mass spectroscopic analysis of the bombykal metabolite.

This work was supported by a MacKnight Foundation grant and NSF grant CHE8509626 to M.R.L.

Correspondence should be addressed to Dr. R. Rybczynski, Section of Molccular Neurobiology, Yale School of Medicine, 333 Cedar St., New Haven, CT 06510.

Copyright (C) 1989 Society for Neuroscience $0270-6474 / 89 / 041341-13 \$ 02.00 / 0$
}

mammals, the possibility that odorants are actively catabolized in the olfactory mucosa has not been rigorously explored, although there are several reports of mucosal oxygenases and dehydrogenases that could play a role in odor catabolism (Gower et al., 1981; Dahl et al., 1982; Casanova-Schmitz et al., 1984). In invertebrates a growing set of data suggests that degradation of biologically important odors by enzymes in the olfactory apparatus is frequent, if not the rule.

In moths, sexually receptive females produce one or more pheromones which serve to attract males and initiate other mating-rclated bchaviors in them. Specialized sensory hairs (sensilla) on the antennae of males contain the dendrites of olfactory neurons that appear to respond solely to sex pheromones (Schneider, 1969). Pheromone-degrading activity has been described from antennae and other body regions of moths (reviewed in Ding and Prestwich, 1986; see also Morse and Meighen, 1984, and Lonergan, 1986), but in most cases it is not known whether the presumed enzyme possesses features needed for it to play a dynamic role in olfaction, i.e., an ability to metabolize physiologically meaningful amounts of pheromone and an appropriate intra-antennal location. However, two sensilla-specific pheromone-degrading enzymes have been reported and characterized to some degree: an esterase from the wild silkmoth Antheraea polyphemus (Vogt and Riddiford, 1981a, b), and an epoxidase from the gypsy moth Lymantria dispar (Vogt, 1987). In addition to the 2 moth enzymes, a 5 '-ectonucleotidase has been described from the purine-sensitive antennae of the spiny lobster Panulirus argus (Trapido-Rosenthal et al., 1987).

This study was undertaken to determine whether a pheromone-degrading enzyme could be found in the sensilla of the tobacco hornworm moth Manduca sexta, which utilizes an aldehydic pheromone and, if so, to determine its possible role in olfaction. We chose to study the metabolic fatc of a sex pheromone in $M$. sexta for several reasons. First, $M$. sexta are easily raised in captivity. Second, females produce a pheromone of known structure, the aldehyde bombykal [(E,Z)-10,12-hexadecadienal], to which males are extremely sensitive (Starratt et al., 1979). Third, a considerable amount of information is already known about the olfactory system of $M$. sexta, particularly in regard to its structure and development (e.g., Sanes and Hildebrand, 1976a, b; Matsumoto and Hildebrand, 1981; Tolbert et al., 1983; Schneiderman et al., 1986). Fourth, it is possible to isolate large numbers of olfactory sensory hairs (sensilla) from $M$. sexta antennae. These sensilla contain the olfactory dendrites within a receptor lymph (Kaissling, 1986).

In this paper we report that $M$. sexta possesses an aldehyde 
oxidase $(\mathrm{AOX})$ that metabolizes its sex pheromone, bombykal. This AOX is unique to the antennae, in which it is secreted into the receptor lymph surrounding the dendrites of the olfactory neurons. The antennal $\mathrm{AOX}$ is devclopmentally regulated in its expression. Biochemical characterization of this AOX suggests that it is related $10 \mathrm{AOXs}$ of mammals and Drosophila and that it has an active site specialized for bombykal oxidation.

\section{Materials and Methods}

Materials. Chemicals of analytical-reagent grade were purchased from Sigma (St. Louis, MO), Baker (Phillipsburg, NJ), Bio-Rad (Richmond, (A), and Aldrich (Milwaukee WI). Electrophoresis-grade chemicals were obtained from Schwars-Mann Biotech (Cleveland, OH), and Bio-Rad. Molecular weight standards (unstained and prestained) for gel electrophoresis were from Bethesda Research Laboratories (Gaithersburg, MD). Nitroblue tetrazolium (NBT), phenazine ethosulfate (PES), 3,3'-diaminobenzidine (DAB), HRP, bovine liver superoxide dismutase, phenylmethylsulfonyl fluoride, and BSA, fraction V, were purchased from Sigma (St. Louis, MO). Bombykal [(E,Z)-10,12-hexadecadienal] was synthesized by J. Reagan (Reagan, 1987). M. sexta eggs were supplied by J. M. Hobgood and M. Jackson (USDA Agricultural Service, 'Lobacco Research Laboratory, Oxford, NC).

Insect Rearing. $M$. sexta were raised as described by Baumhover (1985). Pupae with a completely brown pupal case were defined as day 0 . This state occurs about $4 \mathrm{~d}$ after final instar larvae become aphagic and ambulatory. In our colony eclosion occurs on average on day 16 .

Sample preparation. Antennae and other tissues were collected from animals anesthetized with solid $\mathrm{CO}_{2}$. Samples were kept on solid $\mathrm{CO}_{2}$ before homogenization. Subsequent steps were performed at $4^{\circ} \mathrm{C}$. Material not used the day of collection was stored at $-80^{\circ} \mathrm{C}$.

Sensilla were collected by vortexing 12-20 intact antennae in powdered solid $\mathrm{CO}_{2}$ in a $1.5 \mathrm{ml}$ polypropylene test tube for $3 \mathrm{~min}$ (maximum power; Scientific Manufacturing Industries Multi-tube vortex, model 2600). After vortexing, the $\mathrm{CO}_{2}$ was allowed to sublimate, and the antennae were removed with forceps. The highly hydrophobic sensilla and contaminating antennal scales were washed down from the sides of the tubes and quickly transferred to a single tube using cold acetone. After pelleting $(15,000 \mathrm{~g}$ for $1-2 \mathrm{~min})$, the acetone was removed by pipette and vacuum centrifugation. Extracts of sensilla were prepared by pulse-sonication (Branson sonifier, $40 \%$ power) for 30 sec in 0.15 $\mathrm{ml}$ of $1 \mathrm{mM} \mathrm{NH}_{4} \mathrm{HCO}_{3}, 0.1 \mathrm{~mm}$ PMSF, $1 \mathrm{~mm}$ EDTA, $0.005 \% \mathrm{SDS}$, and $0.1 \% \beta$-mercaptoethanol ( $\beta \mathrm{ME}$ ) (SB buffer). The sonicate was centrifuged for $7 \mathrm{~min}$ at $15,000 \mathrm{~g}$ to remove sensilla and scales and then recentrifuged. The final supernatant was adjusted to $100 \mathrm{~mm} \mathrm{NaPO}$ ( $\mathrm{pH}$ 8.0). Scales were collected by scraping antennae with a fine-tipped scalpel blacle under a dissecting microscope. Whole antennae were homogenized in $\mathrm{SB}$ plus $5 \mathrm{~mm} \mathrm{NaN}_{3}$ and $10 \mu \mathrm{M}$ rotenone for $10 \mathrm{sec}$ (Kinematic PT 10-35; top speed) and treated as above. Extracts for spectrophotometric assay of aldehyde oxidase activity were prepared in $\mathrm{SB}$ without ( $\beta \mathrm{ME}$ because $\beta \mathrm{ME}$ can directly reduce the NBT used in colorometric assays (see below). Protein content of extracts was measured according to Bradford (1976) using bovine serum albumin as the standard.

Bombykal metabolism and thin-layer chromatography. Sensillar extracts prepared from the sensilla of 20 male antennae (about $30 \mu \mathrm{g}$ protein in a volume of $100 \mu \mathrm{l}$ ) were added to borosilicate tubes already containing bombykal or other compounds, thoroughly vortexed, covered, and incubated at $30^{\circ} \mathrm{C}$. The final concentration of substrate was $50 \mu \mathrm{M}$. Although bombykal and bombykol are quite hydrophobic, at 50 $\mu \mathrm{M}$ in the presence of the sensillar proteins, they appeared to be solubilized or dispersed in the extract. After incubation for up to $30 \mathrm{~min}$, the solution was extracted 3 times with equal volumes of diethyl ether. The ether phases were combined, concentrated under vacuum to approximately $25 \mu \mathrm{l}$ and spotted onto a silica TLC plate. The plate was run in pentane : ether : acetic acid (2.0:1.0:0.01). Compounds were visualized with shortwave UV light or by dipping plates briefly in ethanol : water: acetic acid : p-aminobenzaldehyde : sulfuric acid (86.4:4.5:2.6: 2.6:3.9) and developing them over a hot plate $\left(>100^{\circ} \mathrm{C}\right)$.

Gas chromatography/mass spectroscopy. UV-visualized material was scraped from TLC plates and extracted with ether. After extraction the material was treated with diazomethane for $30 \mathrm{~min}$ to form the methyl ester to increase the volatility of extracted material during gas chromatography. Excess diazomethane was removed by purging the solution with dry $\mathrm{N}_{2}$ gas. The solution was then injected into a gas chromatograph/mass spectrometer (HP $5985 \mathrm{GC} / \mathrm{MS}$ cquipped with a $91 \mathrm{~cm}$ OV 101 column) using a column temperature of $150^{\circ} \mathrm{C}$ with a flow rate of $28 \mathrm{mls} / \mathrm{min}$ and an MS setting of $70 \mathrm{ev}$. The GC/MS profile of the bombykal metabolite was compared with that of authentic methyl (E,Z)10,12-hexadecadienoatc. Methyl $(\mathrm{E}, Z)$-10,12-hexadecadienoate was prepared from bombykal as described by Reagan (1987). Briefly, bombykal was dissolved in dimethyl formamide and pyridinium dichromate added. After stirring for $6 \mathrm{hr}, \mathrm{H}_{2} \mathrm{O}$ was added and the mixture was extracted twice with ether. The combined organics were dried over anhydrous $\mathrm{MgSO}_{4}$ and the ether removed in vacuo. The resultant (E,Z)10,12-hexadecadienoic acid was then treated with diazomethane as described above. The purity of the product was verified with gas chromatography and nuclear magnetic resonance

Gel electrophoresis and staining. Reducing SDS-PAGE was performed as described by Laemmli (1970). Sensillar extracts were prepared as described above except that the $\mathrm{NaPO}_{4}$ was not added. $\Lambda$ fter lyophilization to about $30 \mu \mathrm{l}$, an equal volume of SDS sample buffer was added (Laemmli, 1970) and the mixture held at $30^{\circ} \mathrm{C}$ for $10 \mathrm{~min}$ before electrophoresis. Whole antennae and other structures were directly homogenized in SDS sample buffer using a Kinematic PT 10-35 homogenizer at top speed for 10-20 sec. Debris was removed by centrifugation twice for $5 \mathrm{~min}$ at $12,500 \mathrm{~g}$. Protein content was determined using Bradford's (1976) method with BSA as a standard. Following electrophoresis, gels were silver-stained for protein using the method of Ansorge (1985). Aldehyde oxidation was visualized in gels at room temperature using a technique modified from Alderman et al. (1982): gels were washed 5 times $\left(10 \mathrm{~min} /\right.$ wash) with $100 \mathrm{~mm} \mathrm{NaPO}_{4}(\mathrm{pH} 8.0)$ and stained for aldehyde oxidizing activity with $50 \mathrm{~mm}$ propanal, $0.3 \mathrm{~mm}$ $\mathrm{NBT}$, and $0.12 \mathrm{~mm}$ PES in $100 \mathrm{~mm} \mathrm{NaPO}_{4}(\mathrm{pH} \mathrm{8.0)}$. Propanal was used as a substrate in this and most other procedures to conserve bombykal and to avoid problems arising from bombykal's high hydrophobicity. Staining was halted with several washes of $10 \%$ ethanol $/ 5 \%$ acetic acid.

Native gel electrophoresis was performed as described above using the buffer systems of Laemmli (1970) without $\beta \mathrm{ME}$ or SDS. Native gels were stained as described above.

Isoelectric focusing (IEF) was performed following the procedure of O'Farrell (1975). Whole male antennae were directly homogenized in IEF lysis buffer (about $75 \mu \mathrm{l} /$ antenna) using the Kinematic PT 10-35 at top speed for 10 sec. Debris was removed as described above. Samples were electrophoresed at $400 \mathrm{~V}$ for $16 \mathrm{hr}$ and at $800 \mathrm{~V}$ for $\mathrm{l} \mathrm{hr}$. Gels were stained for AOX activity as described for SDS-PACF.

$\mathrm{O}_{2}$ reductase activity. $\mathrm{O}_{2}$ reductase activity of the antennal aldehydeoxidizing enzyme was examined by using a superoxide dismutase-horseradish peroxidase (SOD-HRP) linked assay for $\mathrm{H}_{2} \mathrm{O}_{2}$ generation. SOD $(800 \mathrm{U} / \mathrm{ml})$ and HRP $(100 \mathrm{U} / \mathrm{ml})$ were polymerized in the resolving portion of a native gel. Electrophoresis of sensilla extracts was then performed as usual. After electrophoresis the gel was washed 3-4 times, $5 \mathrm{~min} /$ wash, in $100 \mathrm{mM} \mathrm{NaPO}_{4}(\mathrm{pH} \mathrm{8.0)}$. One or more lanes were then stained in $1 \mathrm{~mm}$ benzaldehyde and $0.05 \% \mathrm{DAB}$ in $\mathrm{NaPO}_{4}(\mathrm{pH} 8.0)$ to reveal proteins capable of oxidizing benzaldehyde and reducing $\mathrm{O}_{2}$. Propanal was not used because at concentrations needed for staining it interacted with the DAB. A parallel gel lane was stained for AOX activity with benzaldehyde, NBT, and PES as described above.

Analysis of $A O X$ activity. Antennal homogenates were prepared as above but minus $\beta \mathrm{ME}$. Each homogenate contained 12 antennae from 6 animals in $1.2 \mathrm{ml}$ of SB. For all studies enzyme activity was measured at $30^{\circ} \mathrm{C}$, and control and experimental conditions were run in triplicate. All experiments were repeated with at least 3 different homogenates. For inhibitor studies, $15 \mu \mathrm{g}$ of antennal protein were preincubated in borosilicate tubes for $3 \mathrm{~min}$ in $100 \mathrm{~mm} \mathrm{NaPO}_{4}(\mathrm{pH} \mathrm{8.0)}$ plus or minus inhibitor (total volume $850 \mu \mathrm{l}$ ). The reaction was started by adding NBT (final concentration $0.3 \mathrm{~mm}$ ), PES (final concentration $0.12 \mathrm{~mm}$ ), and propanal (final concentration $50 \mathrm{~mm}$ ) in $100 \mathrm{~mm} \mathrm{NaPO}_{4}$ (pH 8.0). Reactions were stopped during the period of linear product formation with $100 \mu \mathrm{l}$ of $10 \%$ acetic acid. Nonenzymatic sources of absorbance were determined from tubes to which $10 \%$ acetic acid had been added at time 0 . AOX activity was determined by monitoring the formation of insoluble NBT formazan using light absorbance at $580 \mathrm{~nm}$. AOX activity was converted from absorbance to nmoles of $\mathrm{H}_{2} / \mathrm{min}$ (per mg of protein homogenate or per antenna), transferred from substrate to NBT following the method of Altman (1972) and using a molar absorbance constant $(\epsilon)$ of $0.721 / \mathrm{mmol} / \mathrm{mm}$ (Beuler and Supp, 1983).

Estimates of enzyme kinetic parameters $\left(\mathrm{V}_{\max }\right.$ and $\left.\mathrm{K}_{\mathrm{m}}\right)$ were made by plotting data from 8 to 9 different substrate concentrations on a Hofstee 
graph (Segel, 1976). Reactions were initiated by adding antennal homogenate $(15-40 \mu \mathrm{g}$ protein in $50 \mu \mathrm{l})$ to borosilicate tubes containing the substrate (aldehyde), NBT, and PES in $\mathrm{NaPO}_{4}$ at $30^{\circ} \mathrm{C}$ as above. Reactions were stopped and activity determined as above. Experiments with bombykal were modified to deal with its poor solubility. To maintain an even dispersal of bombykal the assay was changed to include $20 \%$ ethanol and $10 \mu \mathrm{M}$ digitonin. After stopping the reaction an additional $500 \mu \mathrm{l}$ of ethanol was added to solubilize the digitonin micelles, which interfered with spectrophotometry via their light scattering. Assays of benzaldehyde plus and minus ethanol-digitonin yielded similar estimates of kinetic parameters (data not shown), indicating the activity of the AOX is unaffected by these reagents.

The ability of compounds to be reduced, i.e., to serve as electron acceptors, was determined spectrophotometrically, following the methods described by Rajagopalan and Handler (1964)

Analytical gel chromatography. Twenty-five to 30 antennae were homogenized in SB as described above. After centrifugation, Tris- $\mathrm{HCl}$ and $\mathrm{NaCl}$ were added to bring the supernatant to a final concentration of $125 \mathrm{~mm} \mathrm{NaCl}$ and $25 \mathrm{~mm}$ Tris- $\mathrm{HCl}(\mathrm{pH} 7.4)$. Solid $\mathrm{NH}_{4} \mathrm{SO}_{4}$ was added to the solution, and the proteins that precipitated between $50 \%$ and $75 \%$ of saturation were saved for column chromatography. This pellet was dissolved in $0.1 \% \beta \mathrm{ME}, 250 \mathrm{~mm} \mathrm{NaCl}, 50 \mathrm{~mm}$ Tris- $\mathrm{HCl}$, pH 7.4, and applied to a Sephadex G-200 column $(1.5 \times 50 \mathrm{~cm})$ equilibrated with the same buffer (minus the $\beta \mathrm{ME}$ ). The column was previously calibrated with ferritin $\left(M_{r}=440 \mathrm{kDa}\right), \beta$-amylase $\left(M_{r}=200 \mathrm{kDa}\right)$, alcohol dehydrogenase $\left(M_{r}=150 \mathrm{kDa}\right)$ and bovine serum albumin $\left(M_{r}\right.$ $=68 \mathrm{kDa}$ ). One-ml fractions were collected at a flow rate of $3 \mathrm{ml} / \mathrm{hr}$. Propanal, PES, and NBT were added to the fractions, which were then assayed for AOX activity as described above.

Heat inactivation studies. The heat inactivation of AOX in homogenates of whole antennae was determined using a procedure modified from Williamson et al. (1978). Antennae were homogenized in SB without $\beta \mathrm{ME}\left(1\right.$ antenna/ml) as described above. $\mathrm{NaPO}_{4}(\mathrm{pH} 8.0)$ was added to the final supernatant to a final concentration of $100 \mathrm{~mm} \mathrm{NaPO}_{4}$. The homogenate was then incubated at $60^{\circ} \mathrm{C}$, and $75 \mu$ laliquots were taken at 10 -min intervals starting at time 0 . The aliquots were cooled on an ice bath to $4^{\circ} \mathrm{C}$ and then assayed at $30^{\circ} \mathrm{C}$ for AOX activity using the colorometric assay described above.

\section{Results}

\section{Bombykal metabolism in vitro}

Incubation of bombykal with extracts derived from sensilla resulted in the conversion of the pheromone to a new compound as determined by TLC (Fig. 1, lanes B and C). The most likely metabolic fates of an aldehyde are reduction to an alcohol or oxidation to a carboxylic acid. The TLC mobility of the new compound differed from that of bombykol (Fig. 1, lane D), the alcohol analog of bombykal. Bombykol, a pheromone of the silkmoth Bombyx mori (Butenandt et al., 1959), was itself not detectably metabolized by the extract of sensilla (Fig. 1, lanes $\mathrm{D}$ and $\mathrm{E})$. When the new compound was extracted, treated with diazomethane, and analyzed by GC/MS, it was found to match the profile of methyl (E,Z)-10,12-hexadecadienoic acid (Fig. 2). The GC retention time of authentic methyl hexadecadienoate was 7.2 min while the retention time of the methyl esterified metabolite was the same, within experimental error, at $7.3 \mathrm{~min}$. The standard and metabolite also agree in the position of major ion peaks and their relative heights (Fig. 2). The ability of an extract of olfactory sensilla to oxidize bombykal into a carboxylic acid suggested the presence of either an aldehyde dehydrogenase or oxidase in the sensilla.

A second compound, much less abundant than the acid, was also detected in some in vitro experiments. This compound, indicated by a star in Figure 1, lane $\mathrm{C}$, has not yet been identified.

\section{Identification of an aldehyde-oxidizing enzyme}

The bombykal-oxidizing activity in the sensillar extract was found capable of oxidizing other aldehydes, including propanal

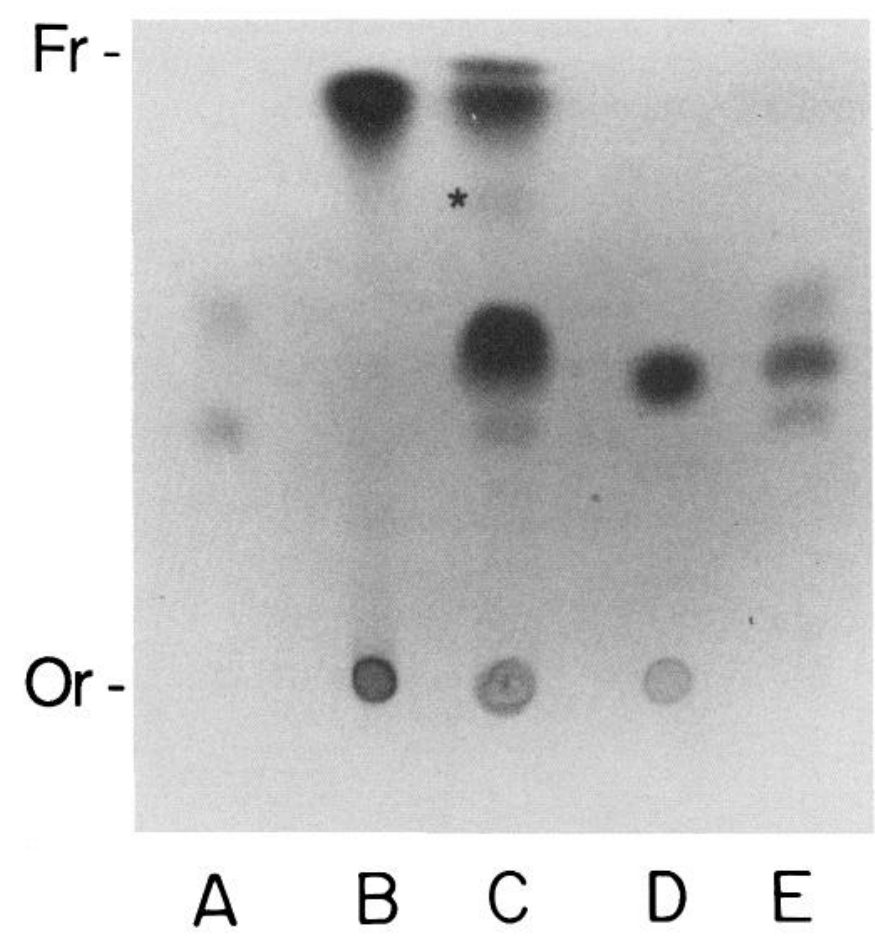

Figure 1. Thin-layer chromatogram: Metabolism of bombykal in sensillar homogenates. Each homogenate contained about $30 \mu \mathrm{g}$ sensillar protein and $50 \mu \mathrm{M}$ substrate in a total volume of $100 \mu \mathrm{L}$. Samples were incubated for $30 \mathrm{~min}$ at $30^{\circ} \mathrm{C}$. Lane: A, Ether extract from sensillar homogenate; B, Bombykal: C, Ether extract from sensillar homogenate incubated for $30 \mathrm{~min}$ at $30^{\circ} \mathrm{C}$. Origin and front of the chromatogram are indicated by $\mathrm{Or}$ and $\mathrm{Fr}$, respectively. Lane: A, Ether extract from sensillar homogenate; B, Bombykal: C, Ether extract from sensillar homogenate incubated with bombykal; D, Bombykol; and E, Ether extract from sensillar homogenate incubated with bombykol. Chromatogram developed with anisaldehyde-sulfuric acid.

and benzaldehyde. Propanal was chosen as a substrate in preliminary assays to identify the antennal component that metabolized aldehydes rather than bombykal because of the latter's low solubility in aqueous solutions.

Initial studies utilizing nondenaturing PAGE revealed the presence of a single, prominent aldehyde-oxidizing band to be present in homogenates of both sensilla and whole antennae (data not shown). This activity could also be visualized after PAGE in the presence of SDS and $\beta \mathrm{ME}$ (Fig. 3). The same band that was initially stained using $5 \mathrm{~mm}$ propanal as a substrate could also be stained using $25 \mu \mathrm{M}$ bombykal (Fig. 3, lanes 3 and 6 ). The activity co-localized with a protein in sensilla of 150 $\mathrm{kDa}(\mathrm{p} 150)$ that was prominent in silver-stained gels (Fig. 3, lane 1). Heating extracts to $90^{\circ} \mathrm{C}$ or more before electrophoresis abolished aldehyde-oxidizing activity (Fig. 3, lane 4) and resulted in the disappearance of p150 and the appearance of a new band at $110 \mathrm{kDa}$ (p110) (Fig. 3, lane 2). Proof that p110 derives from p150 comes from the observation that when the aldehyde-oxidizing band was excised from a gel and re-electrophoresed it yielded a protein of $150 \mathrm{kDa}$ if the gel slice was not boiled and a protein of $110 \mathrm{kDa}$ if the slice was boiled (Fig. 4). Several small polypeptides between 14 and $20 \mathrm{kDa}$ are also apparently released or produced by boiling (Fig. 4, lane B). The bands visible below the p1 10 spot are probably contaminant keratins revealed by the sensitive silver stain, because they were visible in parts of the gel that had not been loaded with protein samples. 


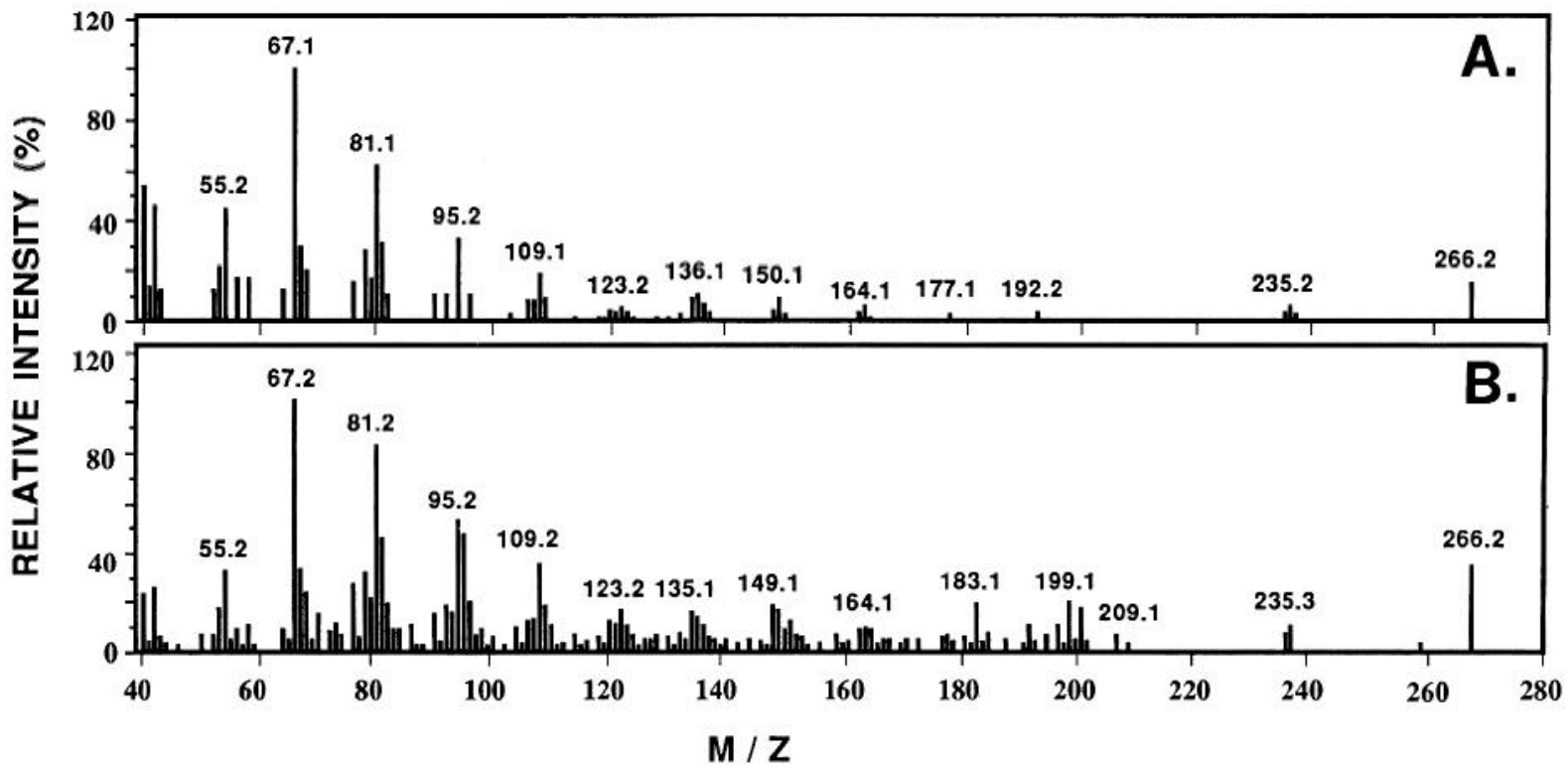

Figure 2. Mass spectra of $(A)$ authentic hexadecadienoic acid (methyl ester), and $(B)$ bombykal metabolite (methyl ester). In $A$, an $\mathrm{M}^{+}$ion is present at 266 , and other major peaks occur at $67,81,95$, and 109 . In $B$, a peak (presumably $\mathrm{M}^{+}$) occurs at 266 . Other major peaks are at 67,81 , 95 , and 109.

\section{Aldehyde oxidation and $\mathrm{O}_{2}$ reductase activity}

Aldehyde oxidation by electrophoresed p150 occurred in the absence of exogenous cofactors. Addition of $\mathrm{NAD}^{+}$did not alter the rapidity or final intensity of gel staining. These data suggested that the antennal enzyme was not a $\mathrm{NAD}(\mathrm{P})^{+}$-requiring dehydrogenase but instead that the enzyme contained a tightly bound cofactor such as FAD. Both oxidases (which can reduce $\mathrm{O}_{2}$ ) and dehydrogenases (which cannot reduce $\mathrm{O}_{2}$ ) are known that have such strongly bound cofactors. To distinguish between these possibilities we first tested for $\mathrm{O}_{2}$ reductase activity using spectrophotometric methods with air- and $\mathrm{N}_{2}$-saturated homogenates. Such experiments yielded equivocal results because of the large number of proteins included and the lack of either an enzyme substrate or a product that could be detected with accuracy and sensitivity. To circumvent this difficulty we devised a SOD-HRP-based gel stain to detect $\mathrm{O}_{2}$ reduction. Figure 5 shows that the aldehyde-oxidizing protein that stained using
NBT as an electron acceptor (lane A) also generated reduced $\mathrm{O}_{2}$, as revealed by HRP-linked staining (lane B). HRP-linked staining was as rapid as when NBT was used. Omission of the AOX substrate, in this case benzaldehyde, abolished staining (Fig. 5, lane C), proving that the antennal enzyme did not directly oxidize $\mathrm{DAB}$, the HRP substrate. Thus the antennal enzyme is an AOX. Whether $\mathrm{O}_{2}$ or another molecule is the electron acceptor in vivo is unknown.

\section{Morphological and developmental expression}

Using gel electrophoresis and the NBT-based gel stain, a variety of M. sexta structures (antennae, eye, proboscis, head, leg, wing, and abdomen) were assayed to determine the morphological distribution of the p150-AOX. Figure 6 shows that AOX activity (detectable at $150 \mathrm{kDa}$ after SDS-PAGE) is present only in antennae. Note also that in contrast to Figure 3 the AOX is not discernible as a distinct silver-stained band in this figure (Fig. 6B, lanes 1 and 2) because protein-rich homogenates of
Figure 3. Molecular weight determination of the antennal aldehyde-oxidizing protein using propanal or bombykal as an oxidation substrate. Sensillar extracts were loaded on a $7.5 \%$ reducing SDS polyacrylamide gel. Lanes 1,2 , and 6 were silver-stained. Lanes 3 and 4 were stained for aldehyde-oxidizing activity using $50 \mathrm{~mm}$ propanal as a substrate. Lane 5 was stained for aldehydeoxidizing activity using $25 \mu \mathrm{M}$ bombykal as a substrate. Extracts for lanes $1,3,5$, and 6 were held at $37^{\circ}$ for 10 min before electrophoresis. Extracts for lanes 2 and 4 were incubated at $90^{\circ}$ for $3 \mathrm{~min}$.

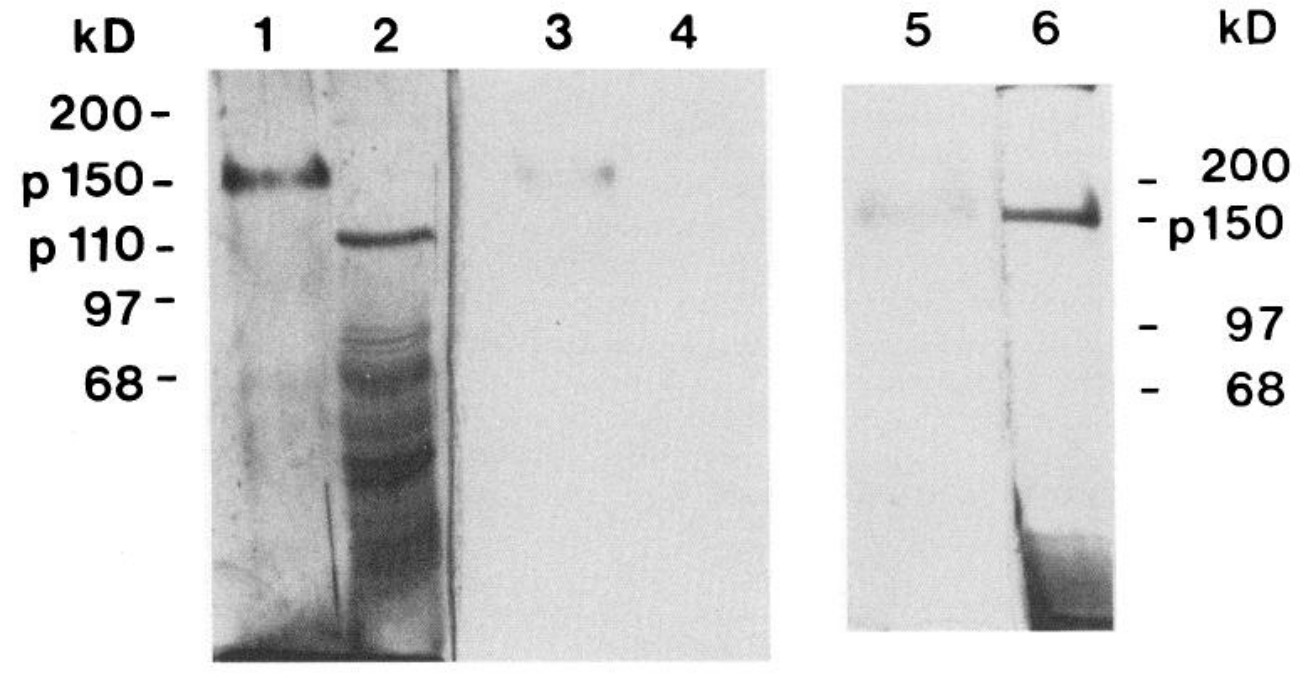




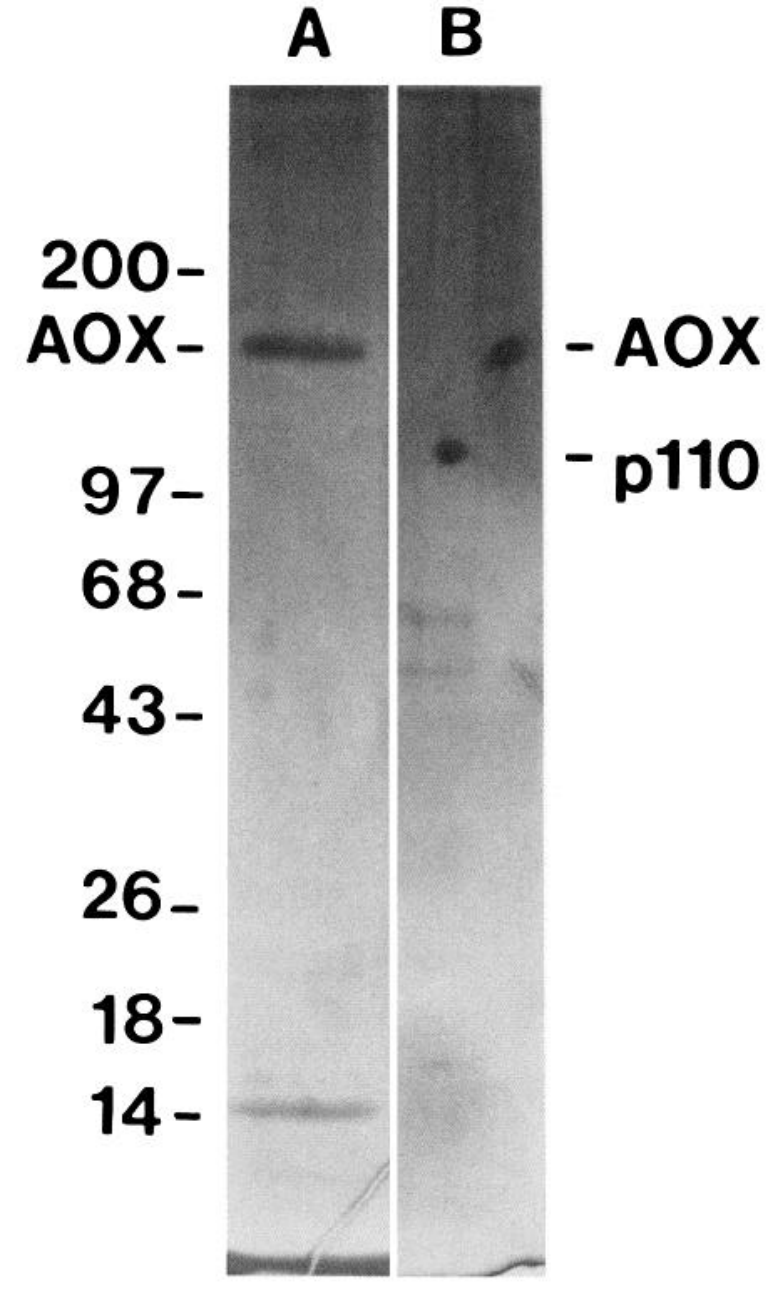

Figure 4. Heat-related molecular weight shift of the antennal aldehyde oxidizing protein. Silver stain of a $5-20 \%$ gradient SDS polyacrylamide gel. Lane A shows a sample of sensillar protein that was loaded directly on the gradient gel (about $30 \mu \mathrm{g}$ of sensillar protein). Lane B shows the proteins that eluted from each of 2 non-SDS-PAGE tube gels (about 30 $\mu \mathrm{g}$ of sensillar protein/tube). After electrophoresis the aldehyde-oxidizing band was located using propanal as a substrate and cut out from each gel. One gel piece was incubated for $10 \mathrm{~min}$ at $30^{\circ} \mathrm{C}$ in SDS sample buffer (Laemmli, 1977) before being placed on the gradient SDS gel (AOX, lane B). The other gel piece was boiled for $4 \mathrm{~min}$ on SDS sample buffer and then held for $6 \mathrm{~min}$ at $30^{\circ} \mathrm{C}$ before being placed on the gradient SDS gel (pl10, lane B).

whole antennae were used instead of extracts from sensilla. Also assayed and negative (not shown) were homogenates of fertilized eggs ( $\approx 1 \mathrm{~d}$ prehatching), 7-d-old larvae, hemolymph from adults and day 3 pupae, and scales from male antennae. Comparison of lanes 2 and 9 in Figure $6 B$ indicate more AOX activity in male than in female antennae. Differences between males and females in AOX levels are analyzed below.

The sensory hairs contain the dendrites of the primary olfactory cells surrounded by a receptor lymph. This lymph is characterized by a very abundant small, hydrophilic protein (the pheromone binding protein; PBP) and contains few other proteins (Vogt and Riddiford, 1981a; Klein, 1987). The AOX coextracts with the PBP (Fig. 7; the PBP is also visible in Fig. 4, lane A). Also note the paucity of proteins in this extract as revealed by silver staining. Like the PBP, the AOX is apparently hydrophilic since: (1) detergents are not needed to extract it

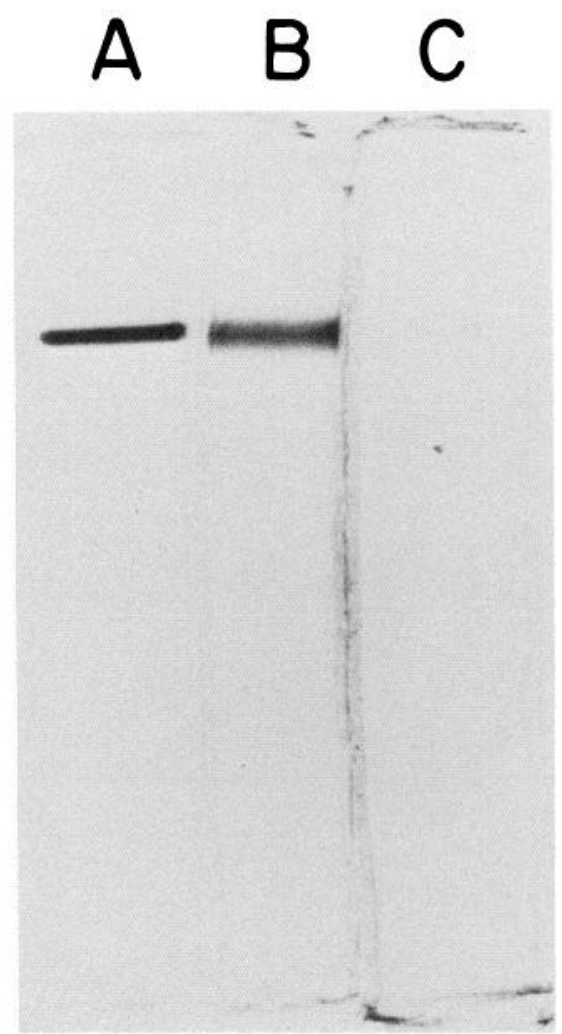

Figure 5. Determination of $\mathrm{O}_{2}$ reductase activity of the antennal AOX. Antennal homogenates were electrophoresed on a $7 \%$ native gel with SOD and HRP polymerized in the resolving portion of the gel. Lane A was stained for benzaldehyde oxidation using NBT as the electron acceptor. Lane B was stained for $\mathrm{O}_{2}$ reductase activity associated with benzaldehyde oxidation using the dye DAB. Lane $C$ was stained for $\mathrm{DAB}$ oxidation in the absence of any aldehydes.

from sensilla, and (2) the AOX retains activity under conditions that are likely to result in loss of activity for a membrane-bound enzyme, i.e., after SDS gel electrophoresis. These data indicate that the AOX is a soluble protein of the receptor lymph.

The developing $M$. sexta antenna is discernible soon after pupation. Antennae from 2 timed cohorts of male pupae were assayed to determine the developmental expression of the AOX Whole antennae were homogenized for this survey because sensilla from pre-eclosion antennae are too soft and flexible to be obtained in quantity. Figure 8 shows that the antennal AOX first reaches detectable levels 3-4 d before eclosion (The presence of the AOX on day -4 is not discernible in the photograph, but is visible in the original gel.) Levels increased up to and including the day of eclosion. After the first appearance of the AOX, the largest difference in AOX levels occurred between animals $2 \mathrm{~d}$ before eclosion ( -2 in Fig. $8 B$ ) and animals $1 \mathrm{~d}$ before eclosion ( -1 in Fig. $8 B$ ).

\section{pH optimum}

The AOX had a pH optimum of 8.0 when homogenates of antennae ( $50 \mu \mathrm{g}$ of protein) were assayed in $100 \mathrm{mM} \mathrm{NaPO}_{4}(\mathrm{pH}$ 8.0 ) with $0.12 \mathrm{~mm}$ PES, $0.3 \mathrm{~mm}$ NBT, and $50 \mathrm{~mm}$ propanal. Activity declined to $44 \%$ of maximum at $\mathrm{pH} 7.0$ and was less than $5 \%$ of maximum at $\mathrm{pH} 6.0$. Aldehyde oxidation at $\mathrm{pH} 8.5$ was $80 \%$ of maximum. Higher $\mathrm{pH}$ values were not assayed 

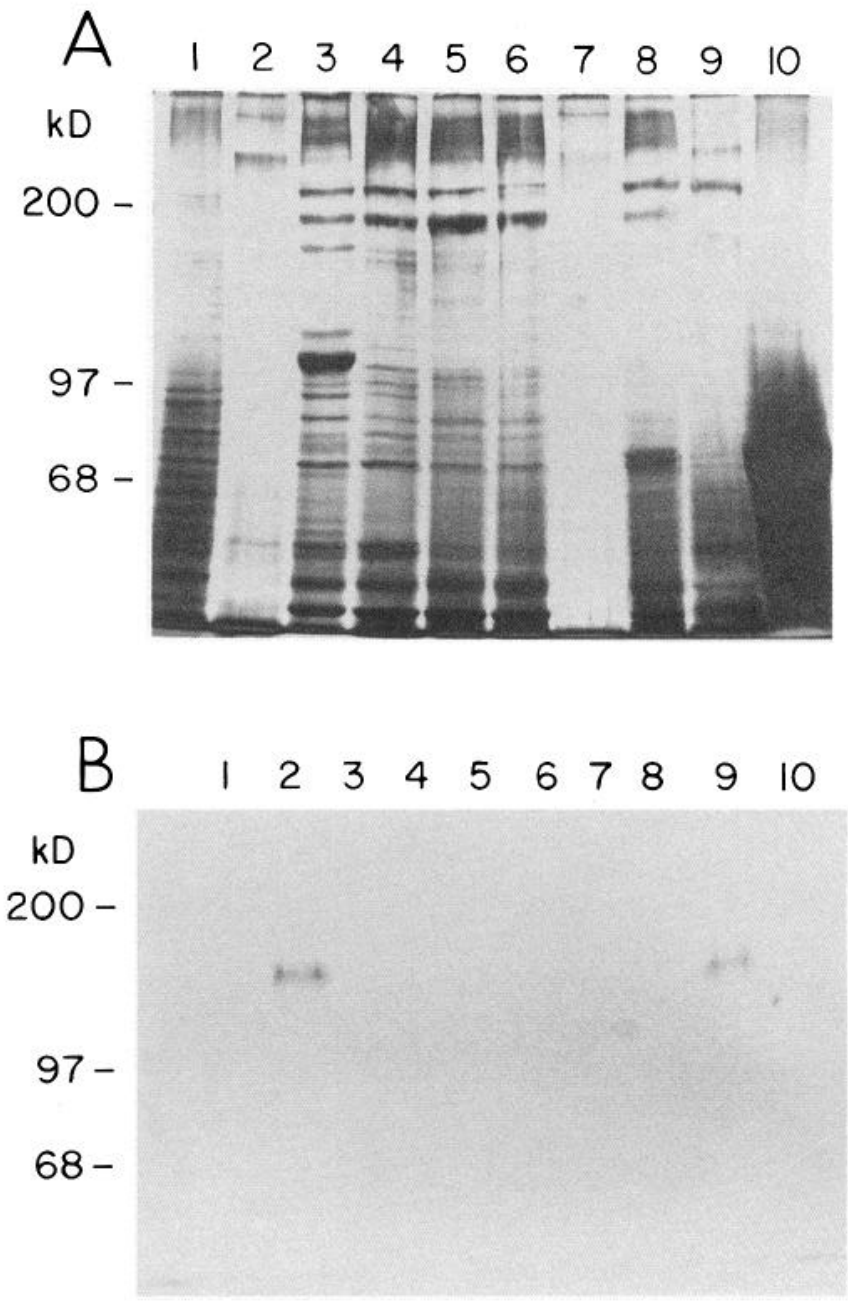

Figure 6. Survey for p150-AOX activity in tissue homogenates from adult $M$. sexta. Homogenates (100 $\mu \mathrm{g} /$ lane) were electrophoresed in $7.5 \%$ reducing SDS polyacrylamide gels. $A$, Silver-stained gel. $B, \mathrm{AOX}$ activity stain. Lane 1, heat-denatured $\left(90^{\circ}\right)$ male antenna; lane 2, male antenna; lane 3, eye; lane 4, proboscis; lane 5, head (minus antennae, eyes, and proboscis); lane 6, leg (equal mixture of fore-, mid-, and hindleg); lane 7 , wing (equal mixture of fore- and hindwing); lane 8 , male abdomen (last 2 segments); lane 9, female antenna; lane 10, female abdomen (last 2 segments).

because rapid nonenzymatic reduction of the NBT resulted in unacceptable backround absorbance. At pH 8.0 the activity of the $\mathrm{AOX}$ in $100 \mathrm{~mm} \mathrm{NaPO}$ or $100 \mathrm{~mm} \mathrm{KPO}_{4}$ is the same, but it is lower $\left(<70 \%\right.$ of activity in $\left.\mathrm{NaPO}_{4}\right)$ in $100 \mathrm{~mm} \mathrm{Na}_{2} \mathrm{~B}_{4} \mathrm{O}_{7}$ or $100 \mathrm{~mm}$ Tris- $\mathrm{HCl}$.

\section{AOX activity in male and female antennae}

Based on staining intensity in gels (e.g., Fig. 6), male antennae appeared to contain more AOX than do female antennae. Using the colorimetric assay we determined the AOX activity in sensilla collected from individual antennae (10 antennae from 10 males and from 10 females, collected within $24 \mathrm{hr}$ of eclosion from animals emerging on pupal days 16 and 17) and from sensilla pooled from 20 male antennae or 30 female antennae. This dual analysis was necessary because of the small amount of protein extractable from the sensilla of an individual antenna $(\leq 2 \mu \mathrm{g})$, an amount too low to allow both an assay of AOX

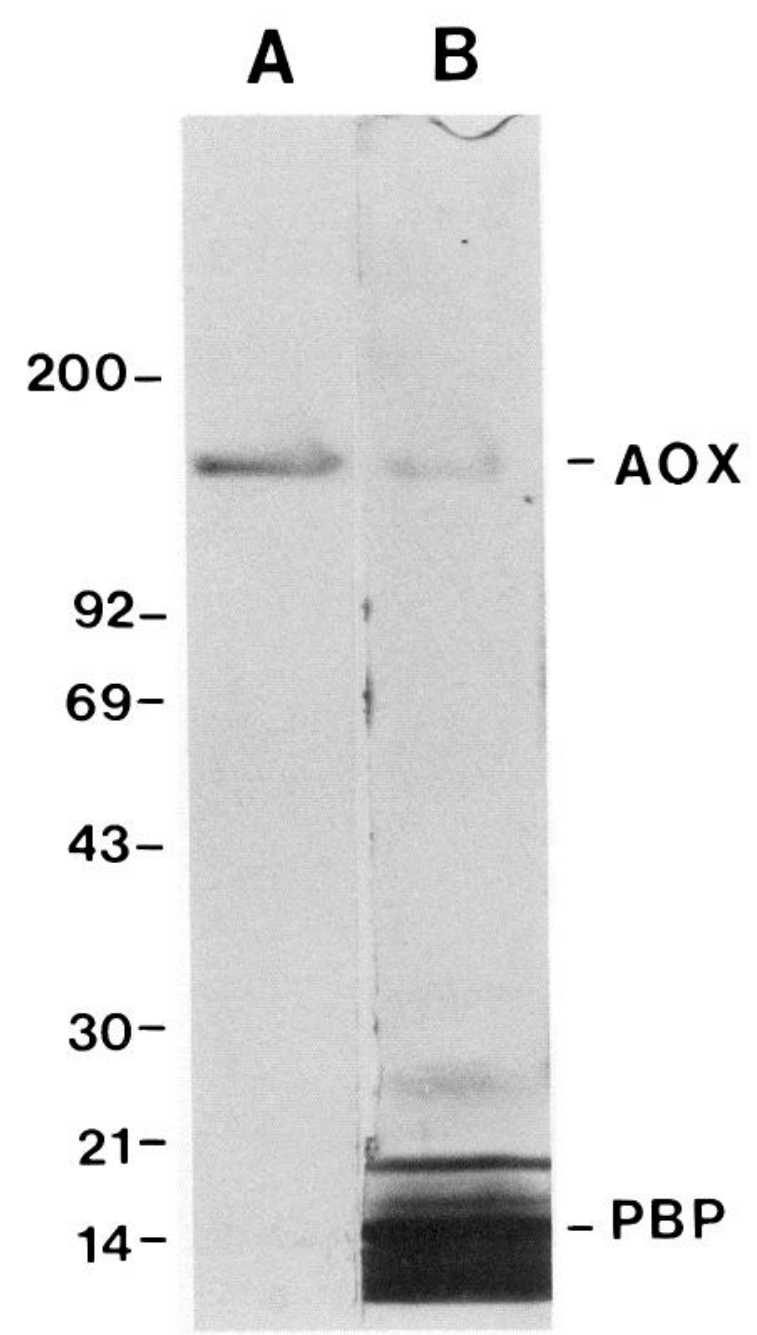

Figure 7. Coextraction of the sensillar AOX and the PBP shown on a $5-20 \%$ gradient SDS gel. Lane A was stained for AOX activity using propanal as a substrate, and lane B was silver-stained to show the cooccurrence of the AOX and PBP. About $15 \mu \mathrm{g}$ of sensillar extract was loaded in each lane before electrophoresis.

activity and an accurate determination of protein content from the same sample.

The sensilla from individual male antennae in this sample averaged about $45 \%$ more AOX activity than did sensilla from female antennae $\left(4.07 \mathrm{nmol} \mathrm{H}_{2} / \mathrm{min} /\right.$ male antenna vs $2.81 \mathrm{nmol}$ $\mathrm{H}_{2} / \mathrm{min} /$ female antenna). Male antennae in the sample exhibited a wider range of AOX activity $\left(0.59-6.67 \mathrm{nmol} \mathrm{H}_{2} / \mathrm{min} / \mathrm{male}\right.$ antenna) than did female antennae $(1.56-4.74 \mathrm{nmol} / \mathrm{min} / \mathrm{female}$ antenna). In the pooled samples, the concentration of AOX in male sensilla was about 2.2 times that in female sensilla (537 $\mathrm{nmol} \mathrm{H}_{2} / \mathrm{min} / \mathrm{mg}$ protein) vs ( $242 \mathrm{nmol} \mathrm{H}_{2} / \mathrm{min} / \mathrm{mg}$ protein) relative to total protein content in the sensilla. When homogenates of whole antennae rather than isolated sensilla were analyzed similar results were obtained, with male antennae containing on average $60 \%$ more AOX activity than did female antennae. Corrected for protein concentration, male antennae contained 2.2 times the activity of female antennae. Homogenates of male antennae also show a greater range of values than did female antennae ( 11 -fold vs 4 -fold, respectively).

These results were obtained from preparations with low detergent concentration $(0.005 \%$ SDS $)$ and the use of higher de- 

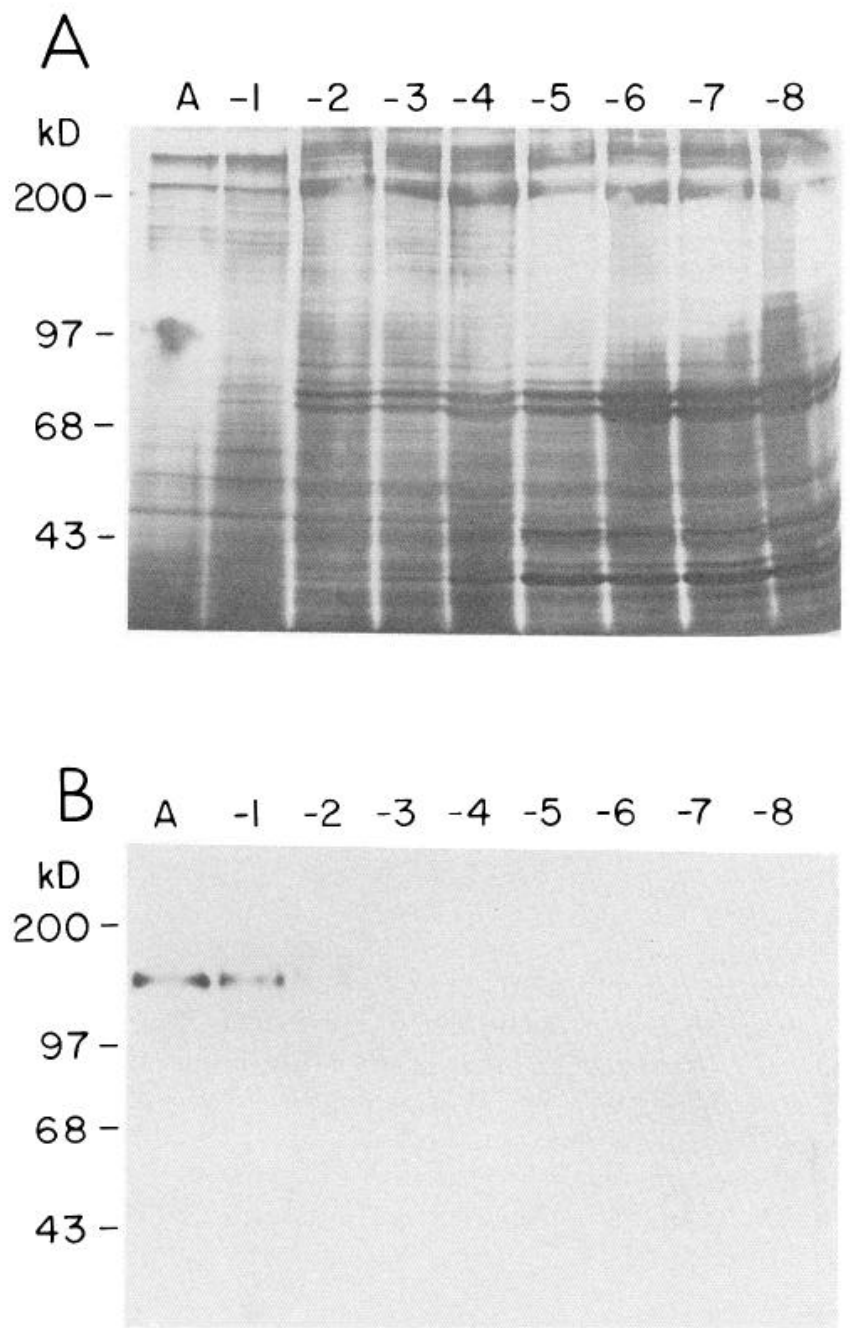

Figure 8. Appearance of p150-AOX activity in developing male antennae. For each time point, antennae were collected from 3 pupae and pooled. Homogenates were electrophoresed in a $7.5 \%$ reducing SDS gel. $A$, Silver-stained gel ( 0.45 antenna/lane). $B$, AOX activity stain (1.125 antennae/lane). Lane A, adult antennae (less than $24 \mathrm{hr}$ after eclosion); Lanes -1 to -8 , pupal antennae from 1-8d before eclosion, respectively.

tergent concentrations would extract more protein and possibly more AOX. However, higher concentrations of both ionic and nonionic detergents could not be used because they produced several types of interferences in the assay.

\section{Molecular weight and isoelectric point determination}

The molecular weight of the sensillar AOX after SDS-PAGE was determined to be $110 \mathrm{kDa}$ for heat-denatured samples and $150 \mathrm{kDa}$ for nondenatured samples (Fig. 4). The average native molecular weight determined from column chromatography was $295 \mathrm{kDa}$, suggesting that the AOX occurs naturally as a dimer (Figure 9). However, the results of gel electrophoresis complicate this interpretation. Two AOX bands can be found on native gels (data not shown). One band, presumably the monomer, exhibits the same mobility as does alcohol dehydrogenase $\left(M_{r}\right.$ $=150 \mathrm{kDa}$ ). The other band, presumably the dimer, runs more slowly than $\beta$-amylase $\left(M_{r}=200 \mathrm{kDa}\right)$ but faster than xanthine oxidase $\left(M_{r}=280 \mathrm{kD}\right)$. The relative abundance of the 2 bands varies among preparations, with the higher weight (dimer) form

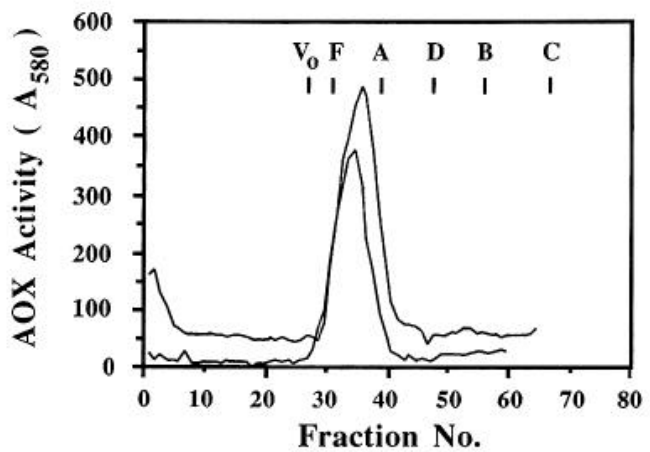

Figure 9. Native molecular weight of the sensillar AOX. Molecular weight was determined on a Sephadex G-200 column previously equilibrated with $250 \mathrm{~mm} \mathrm{NaCl}$ and $50 \mathrm{~mm}$ Tris- $\mathrm{HCl}(\mathrm{pH} \mathrm{7.4})$ and calibrated with the following proteins (elution peaks indicated by $\bullet$ ): Ferritin $(\mathrm{F})$, $M_{r}=440 \mathrm{kDa}$; B-amylase (A), $M_{r}=200 \mathrm{kDa}$; alcohol dehydrogenase (D), $M_{r}=150 \mathrm{kDa}$; bovine serum albumin (B), $M_{r}=68 \mathrm{kDa}$; and cytochrome $\mathrm{C}(C), M_{r}=12 \mathrm{kDa}$. Void volume $\left(V_{o}\right)$ determined with Blue Dextran. AOX activity in 1-ml fractions was determined colorometrically using propanal as a substrate. The curves illustrate 2 separate determinations of AOX activity, yielding molecular-weight estimates of $290 \mathrm{kDa}$ and $300 \mathrm{kDa}$ for the antennal AOX.

predominating. At present it is not clear whether the AOX occurs as a mix of monomer and dimer in vivo or whether the occurrence of some monomer is an artifact of gel electrophoresis. It is also possible that failure to detect monomer in column fractions reflects a lower half-life for active monomer vs dimer since the duration of time from sample preparation to final result is less than $3 \mathrm{hr}$ for electrophoresis but more then $24 \mathrm{hr}$ for analytic chromatography.

On SDS gels the monomer form $(150 \mathrm{kDa})$ predominates and the dimer form is often not detectable. Omission of reducing agent $(\beta \mathrm{ME})$ from the sample buffer did not result in a shift to more dimers. This suggests that the dimer subunits are not held together by disulfide bonds and that the SDS in such gel is sufficient to disassociate them.

IEF of antennal homogenates was performed employing a medium-range $\mathrm{pH}$ gradient of about 5.3-7.9. Under these conditions, a single strongly staining band of AOX activity was found with an isoelectric point of 6.1 (Fig. 10). Electrophoresis of stained AOX bands from IEF gels into a SDS polyacrylamide gel yielded a prominent silver-staining band at $150 \mathrm{kDa}$, confirming that the aldehyde-oxidizing proteins located in IEF and SDS gels are the same. The single band seen in IEF gels is also consistent with the AOX occurring predominantly as a dimer.

\section{Heat inactivation}

Heat inactivation profiles have been determined for AOXs from several strains of Drosophila melanogaster by Dickinson (1975) and Williamson et al. (1978). Most Drosphila strains show a biphasic inactivation with both quickly and slowly inactivating AOXs. A low activity strain (lao) contained only the rapidly inactivating form (Williamson et al., 1978). Under conditions similar to those used by Williamson et al. (1978), we measured the heat inactivation of the $M$. sexta antennal AOX. At $60^{\circ} \mathrm{C}$ the $M$. sexta antennal AOX exhibits a monophasic decline in activity with time (Fig. 11). The estimated half-life of the $M$. sexta enzyme is $29 \mathrm{~min}$. This is nearly twice the half-life of the quickly inactivating form from Drosophila but only about 50\% of the half-life of the more stable Drosophila AOX form [Drosophila half-lives estimated from Williamson et al. (1978)]. 




Figure 10. Isoelectric-point determination of the antennal AOX. IEF in tube gels was performed according to O'Farrell (1975). The standard curve was constructed from $\mathrm{pH}$ gradient generated in 2 gels. Four other gels were stained for AOX activity using propanal as a substrate. Only a single band stained in each gel (apparent pI indicated by $\square$ ).

\section{Substrates and electron acceptors}

The ability of the sensillar AOX to oxidize 3 aldchydes was studied in detail: propanal (a short-chain aldehyde); benzaldehyde (an aromatic aldehyde); and bombykal (a Manduca pheromone that is a 16-carbon, doubly unsaturated aldehyde). Figure 12 shows Hofstee (Segel, 1976) plots of the data from representative experiments with each of the 3 aldehydes, and Table 1 summarizes the Michaelis-Menten parameters derived from all experiments performed with the 3 aldehydes. In all cases the Hofstee plots were linear, and thus there were no indications of a second enzyme oxidizing the substrates or of more than one affinity state of the antennal AOX for any of the aldehydes. The greatest variation among experiments was for the estimates of $V_{\max }$. This variation is consistent with the results obtained in the assay of AOX activity in individual male antennae (see above). Because of bombykal's high hydrophobicity, it was found necessary to use a combination of organic solvent (20\% ethanol) and a nonionic detergent (10 $\mu \mathrm{m}$ digitonin) to maintain consistent substrate concentrations among experiments. This solubilization strategy was chosen for 2 reasons. One, other compounds reacted with the NBT or failed to adequately solubilize bombykal. Two, in pilot experiments the ethanol-digitonin combination did not inhibit or enhance propanal or benzaldehyde oxidation in any detectable way, indicating that the enzyme was unaffected by these conditions.

Based on the $\mathrm{K}_{\mathrm{m}}$, the antennal AOX shows a clear "preference" for bombykal. A quantitative measure of the best substrate for a given enzyme is the ratio $\mathrm{V}_{\max } / \mathrm{K}_{\mathrm{m}}$ (Segel, 1976). The ratios for the 3 substrates of Table 1 are: propanal, 0.05 ; benz-

\begin{tabular}{|c|c|c|}
\hline Substrate & $\mathrm{K}_{\mathrm{m}}$ & $\mathrm{V}_{\max }$ \\
\hline Propanal & $6.8 \mathrm{mM} \pm 1.4^{a}$ & $315.7 \pm 86.7^{b}$ \\
\hline Benzaldehyde & $255.1 \mu \mathrm{M} \quad \pm 16.2$ & $447.3 \pm 112.9$ \\
\hline Bombykal & $5.4 \mu \mathrm{M} \quad \pm 2.1$ & $153.6 \pm 56.8$ \\
\hline
\end{tabular}

Enzyme activity was measured at $30^{\circ} \mathrm{C}$ in homogenates of antennae by spectrophotometrically determining the reduction of NBT (change in absorbance at $580 \mathrm{~nm}$ ). $\mathrm{K}_{\mathrm{m}}$ and $\mathrm{V}_{\max }$ were estimated from Hofstee plots (Segel, 1976). See Figure 12 for representative plots.

"Values presented are the means \pm SEM for 3-5 independent determinations for each substrate.

"Nanomol $\mathrm{H}_{2} / \mathrm{mg}$ antennal protein $/ \mathrm{min}$.



Figure 11. Heat inactivation of the antennal AOX. Homogenates of male antennae in $100 \mathrm{~mm} \mathrm{NaPO}_{4}(\mathrm{pH} 8.0)$ were held at $60^{\circ} \mathrm{C}$, and duplicate aliquots were removed at each time point, chilled to $4^{\circ} \mathrm{C}$, and then assayed colorimetrically for AOX activity at $30^{\circ} \mathrm{C}$ using propanal as a substrate. Each time point is the mean obtained from 3 homogenates. The estimated half-life of the sensillar AOX under these conditions is $29 \mathrm{~min}$.

aldehyde, 1.8; and bombykal, 28.5. These ratios are consistent with a site on the antennal AOX having significant selectivity for bombykal.

Mammalian and Drosophila AOXs are capable of oxidizing a variely of substrates, including some that are not aldehydes (Rajagopalan, 1980). In addition to the 3 aldehydes considered above, we examined 13 other potential substrates at $1 \mathrm{~mm}$ or $250 \mu \mathrm{M}$ concentration, using the oxidation of $1 \mathrm{mM}$ propanal or $250 \mu \mathrm{M}$ benzaldehyde as standards (Table 2). These data reveal several characteristics of the antennal AOX that are summarized as follows. One, carbonyl compounds other than aldehydes are not substrates for the antennal AOX (e.g., acetone, xanthine,

\begin{tabular}{lcc}
\hline Table 2. Oxidation of candidate substrates by the antennal AOX \\
& & Activity \\
Substrate & Concentration & $(\%)$ \\
\hline Propanal & $1 \mathrm{mM}$ & 100 \\
Vanillin & $1 \mathrm{mM}$ & 100 \\
3-ethoxy-r-hydroxy benzaldehyde & $1 \mathrm{mM}$ & 83 \\
2,4,5-trimethoxy-benzaldehyde & $1 \mathrm{mM}$ & 42 \\
Formaldehyde & $1 \mathrm{mM}$ & 38 \\
Pyridoxal & $1 \mathrm{mM}$ & 36 \\
Xanthine & $1 \mathrm{mM}$ & $<1$ \\
Hypoxanthine & $1 \mathrm{mM}$ & $<1$ \\
Acetone & $1 \mathrm{mM}$ & $<1$ \\
Benzaldehyde & $250 \mu \mathrm{M}$ & 100 \\
trans-2-hexenal & $250 \mu \mathrm{M}$ & 87 \\
heptanal & $250 \mu \mathrm{M}$ & 80 \\
m-anisaldehyde & $250 \mu \mathrm{M}$ & 66 \\
p-anisaldehyde & $250 \mu \mathrm{M}$ & 45 \\
Citral & $250 \mu \mathrm{M}$ & 39
\end{tabular}

The oxidation of substrates by the antennal AOX in homogenates of male antennae was determined at $30^{\circ} \mathrm{C}$ by measuring spectrophotometrically the reduction of NBT (at $580 \mathrm{~nm}$ ). All substrates were compared to simultaneous control oxidations of propanal or benzaldehyde. For substrates tested at $1 \mathrm{~mm}$, activity is expressed as a percentage of the activity simultaneously measured in a parallel oxidation of $1 \mathrm{~mm}$ propanal using aliquots of the same enzyme preparation. For substrates tested at $250 \mu \mathrm{M}$, activity is expressed as a percentage of the activity simultancously measured in a parallel oxidation of $250 \mu \mathrm{M}$ benzaldehyde using aliquots of the same enzyme preparation. 


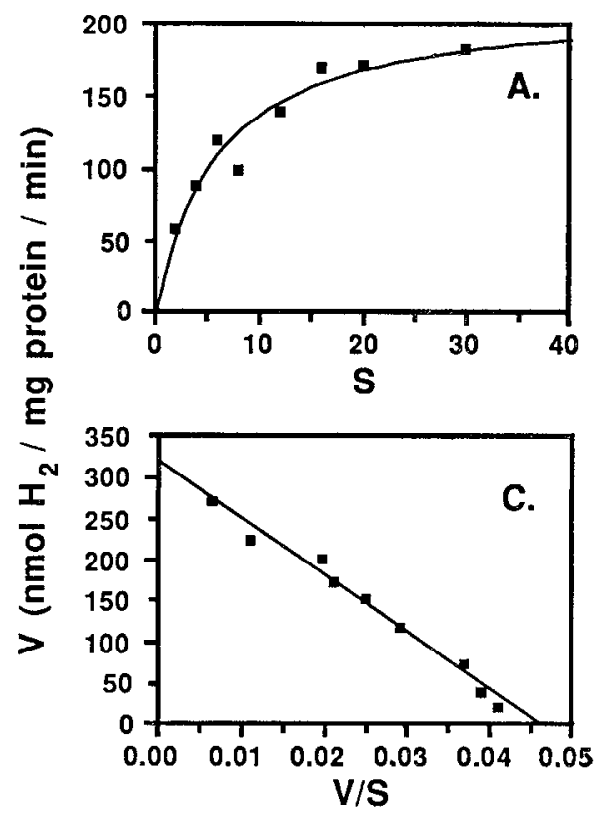

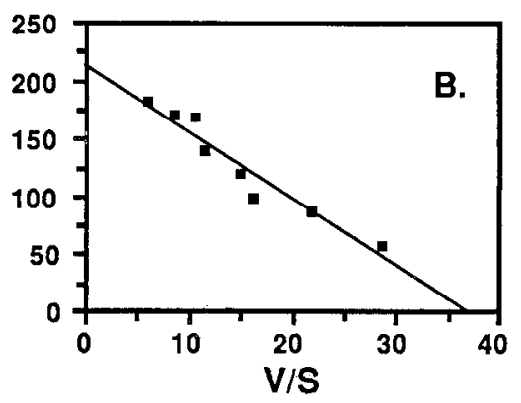

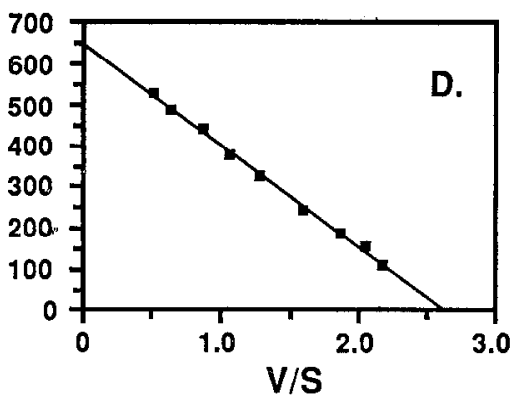

Figure I2. Oxidation of aldehydes by the antennal AOX (Hofstee plots). Each plot shows the results from a representative single experiment using homogenized antennae. Fresh homogenates were used in each experiment. Each point is the mean of 3 replicates (15$40 \mu \mathrm{g}$ antennal homogenate/tube). Eight or 9 concentrations of substrate were assayed in each experiment. Reactions were carried out at $30^{\circ} \mathrm{C}$ for $5 \mathrm{~min}$. Aldehyde oxidation was determined using the absorption of NBT formazan at 580 $\mathrm{mm}$. $A$, Saturation curve for bombykal. The data are the same as shown in $B$, and the curve was generated with the Michaelis-Menten equation using $\mathrm{V}_{\max }$ and $\mathrm{K}_{\mathrm{m}}$ values derived from the Hofstee plot shown in $B ; B$, Oxidation of bombykal $\left(\mathrm{V}_{\max }=213 \mathrm{nmol} \mathrm{H} / \mathrm{mg}\right.$ protein/ $\left.\min ; \mathrm{K}_{\mathrm{m}}=6 \mu \mathrm{M}\right) ; C$, Oxidation of propanal $\left(\mathrm{V}_{\max }=316 \mathrm{nmol} \mathrm{H}_{2} / \mathrm{mg}\right.$ protein/ $\min ; \mathrm{K}_{\mathrm{m}}=7 \mathrm{mM}$ ); and $D$, benzaldehyde $\left(\mathrm{V}_{\max }=645 \mathrm{nmol} \mathrm{H} / \mathrm{mg}\right.$ protein $/ \mathrm{min}$; $\left.\mathrm{K}_{\mathrm{m}}=245 \mu \mathrm{M}\right)$. and hypoxanthine). Two, $\alpha, \beta$ unsaturated aldehydes are good substrates for chemical oxidation, but the presence of this double bond seems to have little effect on the activity of the AOX [in Table 2, compare heptanal (a saturated aldehyde) and trans-2hexenal (an $\alpha, \beta$ unsaturated aldehyde)]. Three, in contrast to the previous point, the oxidation of aromatic aldehydes at a benzilic hydrogen by the AOX does parallel their susceptibility to chemical oxidation. For instance, the addition of side chains slows oxidation (compare benzaldehyde vs other aromatic aldehydes). Finally, if only aliphatic aldehydes are considered (Tables 1 and 2), the antennal AOX shows a strong preference for long- vs short-chain molecules (compare bombykal vs heptanal, trans-2-hexenal and citral vs formaldehyde and propanal).

A range of electron acceptors has been described for a number of mammalian AOXs, e.g., $\mathrm{O}_{2}$, phenazine methosulfate, NBT, 2,6-dichlorophenolindophenol, cytochrome c, ferricyanide, and methylene blue (e.g., Mahler, 1954; Rajagopalan et al., 1962, 1964a), and the Drosophila enzyme can also reduce several acceptors: $\mathrm{O}_{2}, 2,6$-dichlorophenolindophenol, and phenazine methosulfate (Courtright, 1967; Cypher et al., 1982). The Manduca enzyme was also found to be capable of reducing several substrates, including $\mathrm{O}_{2}$ (Fig. 5), phenazine methosulfate, PES, NBT, and ferricytochrome $c$. These experiments were conducted under aerobic conditions with homogenates of whole antennae and $50 \mathrm{~mm}$ propanal as a substrate. Ferricyanide reduction was not detectable under these conditions.

\section{Inhibitors of the sensillar $A O X$}

Inhibitors of rabbit and human liver AOXs have been well characterized (Rajagopalan et al., 1962; Rajagopalan and Handler, 1964a, b; Johns, 1967), and these fall into 2 categories (Rajagopalan, 1980). One group of inhibitors disrupts the internal electron transport chain and the transfer of electrons to acceptors. These include Triton-X 100, antimycin A, some steroids (estradiol and progesterone), hydroquinone, p-hydroxymercuribenzoate, and dinitrophenol. The second group appears to act at or very near the active site of the enzyme. These include quinacrine (a substrate analog), and $\mathrm{CN}^{-}$and methanol, which interact with the molybdenum center. Table 3 shows the inhib- itor sensitivity of the sensillar AOX as measured in whole antennal homogenates. The sensitivity of the antennal AOX to these inhibitors matches that of mammalian AOXs.

\section{Estimate of pheromone half-life in vivo}

The half-life of a substrate can be estimated if the conditions of first order kinetics are met (substrate concentration much lower than the $\left.\mathrm{K}_{\mathrm{m}}\right)$ from the equation $\mathrm{t}_{1 / 2}=\left(\ln 2 /\left(\mathrm{V}_{\max } / \mathrm{K}_{\mathrm{m}}\right)\right.$ (Segel, 1976). Vogt et al. (1985) have made an estimate for a half-life in the sensilla of about $15 \mathrm{msec}$ for the ester pheromone [(E,Z)-6,11-hexadecadienyl acetate] of the silkmoth $A$. polyphemus. To make this estimate they made 2 assumptions: (1) First-

\begin{tabular}{lcc}
\hline $\begin{array}{l}\text { Table 3. Effect of inhibitors on propanal oxidation by the antennal } \\
\text { AOX }\end{array}$ & & \\
& Concentration & $\%$ Inhibition $^{a}$ \\
Inhibitor & $10 \mu \mathrm{M}$ & 62 \\
\hline $\mathrm{CN}^{-}$ & $50 \mu \mathrm{M}$ & 30 \\
Dinitrophenol & $10 \mathrm{mM}$ & 42 \\
Hydroquinone & $50 \mu \mathrm{M}$ & 83 \\
$\rho$-hydroxymercuribenzoate & $1 \mathrm{mM}$ & 24 \\
Quinacrine & $10 \mu \mathrm{M}$ & 43 \\
Antimycin & $50 \mu \mathrm{M}$ & 41 \\
$\beta$-estradiol & $50 \mu \mathrm{M}$ & 14 \\
$\beta$-ecdysone & $0.01 \%$ & 81 \\
Triton-X 100 & \\
Methanol & $0.3 \mathrm{M}$ & 58 \\
Ethanol & $3.45 \mathrm{M}$ & 0 \\
Rotenone & $10 \mu \mathrm{M}$ & 0 \\
NaN & $5 \mathrm{mM}$ & 0 \\
Na deoxycholate & $240 \mu \mathrm{M}$ & 0 \\
Digitonin & $125 \mu \mathrm{M}$ & 0
\end{tabular}

Fifteen $\mu \mathrm{g}$ of antennal homogenate were preincubated with inhibitor for $3 \mathrm{~min}$ at $30^{\circ} \mathrm{C}$ before substrate was added. The reaction was stopped after $5 \mathrm{~min}$ at $30^{\circ} \mathrm{C}$. Enzyme activity was monitored by spectrophotometrically measuring the reduction of NBT $(580 \mathrm{~nm})$.

"Mean of 3 independent determinations, conducted with parallel inhibitor-free reactions.

"No preincubation. 
order kinetics applied because the $K_{m}$ of the esterase was $10^{6}$ higher than the physiological threshold of the antennnal response; and (2) essentially all of the esterase is present in the receptor lymph. Two additional assumptions were made to calculate substrate half-lives in $M$. sexta sensory hairs: (1) The volume of lymph per male-specific sensillum in $M$. sexta is the same as in $A$. polyphemus $\left(10^{-12}\right.$ liter: Gnatzy et al., 1984; Vogt et al., 1985), and (2) the amount of AOX activity in male-specific sensilla is proportional to the amount of AOX activity in homogenates of male antennae above that found in homogenates of female antennae. (We found that antennae from males contained $60 \%$ more $\mathrm{AOX}$ activity than did antennae from females, and so we assume that $37.5 \%$ of the AOX activity in antennae from males is found in the male-specific sensilla.) With these assumptions we estimated the half-life of bombykal in the malespecific sensilla of $M$. sexta to be about $0.6 \mathrm{msec}$. To do this we converted the $\mathrm{V}_{\max }$ (Table 1) into a per-sensillum value as follows. The $\mathrm{V}_{\max }\left(153 \mathrm{nmol} \mathrm{H}_{2} / \mathrm{mg}\right.$ protein $\left./ \mathrm{min}\right)$ was multiplied by 0.26 (mg protein/antenna) and divided by $60(\mathrm{sec} / \mathrm{min})$ to yield a per antenna $V_{\text {max }}$ of $663 \mathrm{pmol} /$ antenna $\cdot \mathrm{sec} \cdot$ liter. Note that it is necessary to express the $V_{\max }$ as a $V_{\max }$ /liter because of the expression of the volume of a sensillum in liters (see below). This value was then multiplied by 0.375 (the fraction of the AOX found in male-specific sensilla) and by $1 /(40,000$ [sensilla/ antenna (Sanes and Hildebrand, 1976a) $\times 10^{-12}$ [liters/sensillum]) to yield an adjusted $\mathrm{V}_{\max }$ of $6.2 \times 10^{-3} \mathrm{~mol} / \mathrm{sensillum} /$ sec. As Vogt et al. (1985) point out, this $\mathrm{V}_{\max }$ estimate may be an underestimate because it assumes no loss of enzyme in processing samples. Underestimating $\mathrm{V}_{\max }$ yields overestimates the half-life.

Using the same logic, we made half-life calculations for benzaldehyde and propanal in the much smaller, non-pheromoneresponsive olfactory sensilla found on the antennae of both sexes [(55,000 per antenna (Sanes and Hildebrand, 1976a) using an estimate of lymph volume/sensillum of $2.5 \times 10^{-13}$ liter (probably an overestimate)]. The calculated per-sensillum $\mathrm{V}_{\max }$ for benzaldehyde is $88.3 \times 10^{-3} \mathrm{~mol} / \mathrm{sensillum} / \mathrm{sec}$, and for propanal it is $62.2 \times 10^{-3} \mathrm{~mol} / \mathrm{sensillum} / \mathrm{sec}$; the estimated halflives for benzaldehyde and propanal are $2 \mathrm{msec}$ and $76 \mathrm{msec}$, respectively. If the lymph volume per sensillum is smaller than that used in our calculation, then the half-lives will be proportionally shorter.

\section{Discussion}

Characterization of the Manduca sensillar $A O X$

The biochemical characteristics of the $M$. sexta AOX reveal both similarities and differences when compared to AOXs in mammals and Drosophila. The mammalian and Drosophila enzymes are homodimers with subunits of 140-150 kDa, respectively (Andres, 1976; Rajagopalan, 1980). When the $M$. sexta AOX is not subject to heat denaturation (see below), it also occurs as a dimer (Fig. 9) with a subunit size of $145-150 \mathrm{kDa}$ (Fig. 3). After nondenaturing gel electrophoresis a small fraction appeared as the monomer, but this may be an artifact of sample manipulation. The antennal AOX appears to be a homodimer and not a heterodimer with subunits of equal size, because 2-dimensional electrophoresis of sensillar extracts revealed only a single protein of $M_{r}=150 \mathrm{kDa}$, and heat denaturation of the dimer followed by SDS-PAGE converts the AOX to a $110-\mathrm{kDa}$ form (Fig. 3). It is unlikely that 2 different proteins would have the same molecular weight and isoelectric point and also show the same heat-related molecular weight shift. Also, the monotonic decline of activity at $60^{\circ} \mathrm{C}$ (Fig. 11) is consistent with the AOX being a homodimer.

The antennal AOX is sensitive to all inhibitors of the mammalian AOXs to which it has been exposed (Table 3). Some of these inhibitors interfere with electron transport among the prosthetic groups of mammalian AOXs, e.g., p-hydroxymercuribenzoate (sulfur groups) and $\mathrm{CN}^{-}$and methanol (molybdopterin cofactor; Johnson et al., 1980; Rajagopalan, 1980). Further purification of the $M$. sexta enzyme will be necessary to test it for the $\mathrm{Fe}, \mathrm{Mb}$, and FAD cofactors typical of mammalian and Drosophila AOXs.

The $M$. sexta enzyme is capable of oxidizing a variety of aldehydes (Table 2), as are mammalian (Rajagopalan and Handler, 1964b; Johns, 1967) and Drosophila (Dickinson, 1978; Cypher et al., 1982) AOXs. All 3 types of AOX metabolize small aliphatic aldehydes with apparent $\mathrm{K}_{\mathrm{m}}$ in the low millimolar range. Benzaldehyde is a relatively good substrate for mammalian and Drosophila AOXs $\left(\mathrm{K}_{\mathrm{m}}\right.$ of $\left.10-20 \mu \mathrm{M}\right)$ but it is an appreciably poorer one for the sensillar $\mathrm{AOX}\left(\mathrm{K}_{\mathrm{m}}=255 \mu \mathrm{M}\right)$. Both the Drosophila and $M$. sexta antennal AOXs oxidize 2,4,5trimethoxybenzaldehyde very poorly (Cypher et al., 1982; Table 2 , this report). Pyridoxal is a good substrate for mammalian enzymes but not for the $M$. sexta antennal or Drosophila AOXs (Courtright, 1967; Rajagopalan, 1980; Table 2, this report). Nonaldehyde substrates for mammalian AOXs have been well characterized, e.g., purines, pyrimidines, and quinolines (Rajagopalan, 1980). Purines are good substrates for $-\mathrm{N}$ and $-\mathrm{C}$ hydroxylation by some mammalian AOXs, but they were not detectably oxidized by the $M$. sexta AOX. Taken together, these data suggest that the $M$. sexta antennal AOX is more related to the Drosophila enzyme than to the mammalian AOXs.

More importantly, these data can be used to infer several aspects of the oxidation of substrates by the sensillar AOX. One, the enzyme is specific for aldehydes, and other carbonyl groups are not oxidized (e.g., xanthine and acetone, Table 3). Two, if the aliphatic aldehydes are considered (Tables 2 and 3), the antennal AOX shows a preference for longer aldehydes (Table 3 ). However, the ability of the antennal AOX to oxidize aromatic aldehydes argues against an enzyme site that simply recognizes long hydrocarbons and for an enzyme that recognizes 2 or more properties of potential substrates.

The antennal AOX of $M$. sexta differs from mammalian and Drosophila AOXs in at least 2 major biochemical features. First, following heating to $90^{\circ} \mathrm{C}$, the enzyme exhibits an apparent shift in monomer size from $150 \mathrm{kDa}$ to $110 \mathrm{kDa}$ (Fig. 4). A shift of $M_{r}$ with heating has not been reported for other AOXs. Heating also results in the release or production of 1 or 2 polypeptides $(\leq 20 \mathrm{kDa}$ ) in addition to the $110 \mathrm{kDa}$ form. It is unclear whether these are proteolytic fragments or tightly associated, independent gene products. This problem may be resolved only when the coding sequence for the AOX is determined. Second, the antennal AOX is found in an extracellular compartment (receptor lymph; see below). We are unaware of any other extracellular AOXs; the reported mammalian and Drosophila AOXs are all intracellular (Rajagopalan et al., 1962; Cypher et al., 1982).

\section{Tissue and temporal distribution of the antennal $A O X$}

The antennal AOX is found only in antennae (Fig. 6). In contrast, mammalian and Drosophila AOXs are found in a variety of tissues (Rajagopalan et al., 1962; Holmes, 1978; Cypher et 
al., 1982). Additionally, 3 lines of evidence suggest that the AOX is not only limited to the antennae but is specifically located in the extracellular receptor lymph bathing the dendrites of the primary olfactory neurons. One, the AOX is extractable from sensilla without the use of detergents needed to release membrane-bound or intracellular proteins. Two, the AOX coextracts with a very abundant small protein (16 kDa, Fig. 7) that is homologous to the PBP described from other moth species (Györgyi et al., 1988). This PBP is characteristic of the receptor lymph of sensilla (Vogt and Riddiford, 1981a, b; Kaissling et al., 1985). Three, the antennal AOX does not require a soluble cofactor such as $\mathrm{NAD}(\mathrm{P})^{+}$to oxidize aldehydes. An enzyme would not be expected to require such cofactors, and the additional enzymes or transport systems needed to recycle or replace cofactors, if it were to be efficient in an extracellular environment.

The tightly regulated temporal cxpression of the antennal AOX is also unique relative to AOXs of other organisms. For instance, the Drosophila AOX reaches high levels in adults but is also expressed in many tissues in larval and pupal animals (Dickinson, 1975; Cypher et al., 1980). The antennal AOX (see Fig. 5), the PBP (Györgyi et al., 1988), and electrophysiological responsiveness to aldehyde odors (Schweitzer et al., 1976; J. Reagan and M. R. Lemer, unpublished observations) are all first detectable at the same time, about $3 \mathrm{~d}$ before eclosion. This suggests a common regulatory pathway for the mature antennal phenotype.

The cell type that synthesizes the sensillar AOX and exports it to the receptor lymph has not yet been identified. In addition to the olfactory neurons that innervate the sensory hairs, 3 types of auxiliary cells are found at the base of the sensillum. Two of these types, trichogen and tormogen cells, have strongly folded apical membranes that border the lymph cavity and may be involved in production of components of the receptor lymph (Steinbrecht and Gnatzy, 1984) such as the AOX.

\section{The role of the sensillar $A O X$ in olfaction}

One requisite of a sensitive olfactory system is a mechanism to limit the number of times that a given odor molecule can bind to a receptor. If odor half-life is not regulated in some way, for instance by enzymic degradation, transport, or physical sequestration, an animal will be relatively insensitive to temporospatial changes of odor concentration in the environment. Any enzyme that is a candidate for modulating olfactory sensitivity, especially to pheromones, must meet several criteria: (1) It must be relatively efficient at metabolizing the substrate odors(s); (2) it should be found in the same morphological compartment as the odor receptors; and (3) it must be found in sufficient concentration to metabolize physiologically meaningful concentrations of substrate. The antennal AOX of $M$. sexta meets these criteria, particularly in regard to the metabolism of the $M$. sexta sex pheromone, bombykal. First, the antennal AOX not only is capable of oxidizing a variety of aldehydes, but it also appears to be specialized for oxidizing bombykal. If the ratio of $\mathrm{V}_{\max }$ / $\mathrm{K}_{\mathrm{m}}$ is used as a criterion to determine the "best" substrate for the AOX (Segel, 1976), bombykal $\left(\mathrm{V}_{\max } / \mathrm{K}_{\mathrm{m}}=28.5\right)$ is a notably better substrate than benzaldehyde $\left(\mathrm{V}_{\max } / \mathrm{K}_{\mathrm{m}}=1.8\right)$, the next best substrate (see Tables 1,2). Second, the antennal AOX is located in the sensillar lymph that bathes the dendrites of the primary olfactory neurons. These dendrites are the site of general olfactory and pheromone receptors (Schneider, 1969; Kaissling, 1986; Vogt et al., 1988). Third, the calculated half-life of bom- bykal in sensory hairs $(0.6 \mathrm{msec})$ based on our estimates of in vivo pheromone and enzyme concentration suggest that the antennal AOX can easily metabolize physiologically meaningful amounts of bombykal.

Two other characteristics of the antennal AOX reinforce the view that the AOX plays a role in modulating the moths' perception of aldehyde odors. First, the antennal AOX of $M$. sexta is expressed only in that tissue. Second, the antennal AOX is developmentally regulated in a way that parallels the development of a functional sense of smell in $M$. sexta (Schweitzer et al., 1976; J. Reagan and M. R. Lerner, unpublished observations). It is likely that any protein that plays a special role in the sense of smell will be limited to olfactory tissues and will be expressed only when a functional sense of smell is present.

Several characteristics of the $M$. sexta antennal AOX are similar to those of the sensillar (antennal) esterase of the silkmoth $A$. polyphemus described by Vogt and coworkers (Vogt and Riddiford, 1981a, b; Vogt et al., 1985). Both enzymes are expressed only in antennae and are soluble proteins of the receptor lymph. The $\mathrm{K}_{\mathrm{m}}$ s of the enzymes for their respective pheromones are also similar: $5 \mu \mathrm{M}$ for bombykal in $M$. sexta and 2 $\mu \mathrm{M}$ for (E,Z)-6,11-hexadecadienyl acetate in $A$. polyphemus. The half-lives of molecules of the 2 pheromones that enter sensilla, based on estimates of esterase and AOX concentrations in the sensilla of the 2 species, are also comparably short: about 0.6 msec in $M$. sexta and $15 \mathrm{msec}$ in $A$. polyphemus. However, the esterase and AOX do differ in one notable way. The silkmoth antennal esterase is male-specific (Vogt and Riddiford, 1981a). In contrast, the $M$. sexta antennal AOX is found in both sexes (Fig. 6), although it is more abundant in males. Since antennae from both sexes of $M$. sexta respond strongly to the aldehyde trans-2-hexenal (Schweitzer et al., 1976; Reagan and Lerner, unpublished observations), a common leaf component (Visser et al., 1979), non-pheromonal aldehydes may be important olfactory cues to one or both of the sexes in behaviors such as food finding (both sexes feed as adults), habitat selection, or choice of egg-laying sites. The estimated intrasensillar half-lives of benzaldehyde $(2 \mathrm{msec})$ and propanal $(76 \mathrm{msec})$, which are moderate to poor substrates for the antennal $\mathrm{AOX}\left(\mathrm{K}_{\mathrm{m}}=255\right.$ $\mu \mathrm{M}$ and $6 \mathrm{mM}$, respectively), are still relatively short. This suggests a possible modulating role of the enzyme in the perception of non-pheromone aldehydes because these times are equal to or less than the time required for the decay of the electrophysiological response when trans-2-hexenal stimulation of antennae is halted (Schweitzer et al., 1976). Thus the antennal AOX of $M$. sexta may play a dual role in olfaction. First, it may serve a special purpose in sex pheromone metabolism via its greater expression in male antennae. Second, it may function to degrade general aldehyde odors in both sexes. As a dual-function olfactory enzyme, the $M$. sexta AOX may be representative of a class of enzymes intermediate between the sex-specific pheromonedegrading esterase of $A$. polyphemus (Vogt and Riddiford, 1981a, b) and the sex-indifferent 5 '-ectonucleotidase of $P$. argus (Trapido-Rosenthal et al., 1987).

\section{References}

Alderman, J., C. G. Sanny, E. D. Gordon, and C. S. Lieber (1982) Partial characterization of hepatic aldehyde dehydrogenase from the baboon. In Enzymology of Carbonyl Metabolism: Aldehyde Dehydrogenase and Aldo/Keto Reductase, $\mathrm{H}$. Weiner and B. Wermuth, eds., pp. 77-89, Liss, New York.

Altman, F. P. (1972) Quantitative dehydrogenase histochemistry with 
special reference to the pentose shunt dehydrogenaes. Progr. Histochem. Cytochem. 4: 225-273.

Andres, R. Y. (1976) Aldehyde oxidase and xanthine dehydrogenase from wild-type Drosophila melanogaster and immunologically crossreacting material from $m a-1$ mutants. Eur. J. Biochem. 62: 591-600.

Ansorge, W. (1985) Fast and sensitive detection of protein and DNA bands by treatment with potassium permanganate. J. Biochem. Biophys. Methods 11: 13-20.

Baumhover, A. H. (1985) Manduca sexta. In Handbook of Insect Rearing, Vol. 2, P. Singh and R. F. Moore, eds., pp. 387-400. Elsevier, Amsterdam.

Beuler, H.-O., and M. Supp (1983) Coenzymes, metabolites and other biochemical reagents. In Methods of Enzymatic Analysis, Vol. II, H. U. Bergmeyer, ed., p. 373, Weinheim, Deerfield Beach, FL.

Bradford, M. M. (1976) A rapid and sensitive method for quantification of microgram quantities of protein utilizing the principle of protein-dye binding. Anal. Biochem. 72: 248-254.

Butenandt, A., R. Beckmann, D. Stamm, and E. Hecker (1959) Über den Sexual-Lockstoff des Seidenspinners Bombyx mori: Reindanstellung und Konstitution. Z. Naturforsch. 14b: 283-284.

Casanova-Schmitz, M., R. M. David, and H. D'A. Heck (1984) Oxidation of formaldehyde and acetaldehyde by $\mathrm{NAD}^{+}$-dependent dehydrogenases in rat nasal mucosal homogenates. Biochem. Pharm. 33: $1137-1142$.

Courtright, J. B. (1967) Polygenic control of aldehyde oxidase in Drosophila. Genetics 57: 25-39.

Cypher, J. J., J. L. Tedesco, J. B. Courtright, and A. K. Kumaran (1982) Tissue-specific and substrate-specific detection of aldehyde and pyridoxal oxidase in larval and imaginal tissues of Drosophila melanogaster. Biochem. Gen. 20: 315-332.

Dahl, A. R., W. M. Hadley, F. F. Hahn, J. M. Benson, and R. O. McClellan (1982) Cytochrome P-450-dependent monooxygenases in olfactory epitheliun of dogs: Possible role in tumorigenicity. Science 216: $57-59$.

Dickinson, W. J. (1975) A genetic locus affecting the developmental expression of an enzyme in Drosophila melanogaster. Devel. Biol. 42. $131-145$.

Dickinson, W. J. (1978) Genetic control of enzyme expression in Drosophila: A locus influencing tissue specificity of aldehyde oxidase. J. Exp. Biol. 206: 333-342.

Ding, Y.-S., and G. D. Prestwich (1986) Metabolic transformation of tritium-labeled pheromone by tissues of Heliothis viresens moths. J. Chem. Ecol. 12: 411-429.

Getchell, T. V., F. L. Margolis, and M. L. Getchell (1984) Perireceptor and receptor events in vertebrate olfaction. Prog. in Neurobiol. 23: 317-345.

Gnatzy, W., W. Mohren, and R. A. Steinbrecht (1984) Pheromone receptors in Bombyx mori and Antheraea pernyi. II. Morphometric analysis. Cell Tissue Res. 235: 35-42.

Gower, D. B., M. R. Hancock, and L. H. Bannister (1981) Biochemical studies on boar pheromones, 5-androst-16-en-3-one and 5-androst16-en-3-ol, and their metabolism by olfactory tissue. In Biochemistry of Taste and Olfaction, R. H. Cagan and M. R. Kare, eds., pp. 8-32, Academic, New York.

Györgyi, T. K., A. J. Roby-Shemkovitz, and M. R. Lerner (1988) Characterization and CDNA cloning of the pheromone-binding protein from the tobacco hornworm, Manduca sexta: A tissue-specific developmentally regulated protein. Proc. Natl. Acad. Sci. USA 85: 9851-9855.

Holmes, R. S. (1978) Electrophoretic analysis of alcohol dehydrogenase, aldehyde oxidase, sorbitol dehydrogenase, and xanthine oxidase from mouse tissues. Comp. Biochem. Physiol. 6IB: 339-346.

Johns, D. G. (1967) Human liver aldehyde oxidase: Differential inhibition of oxidation of charged and uncharged substrates. J. Biol. Chem. 46: 1492-1505.

Johnson, J. L., B. E. Hainline, and K. V. Rajagopalan (1980) Characterization of the molybdenum cofactor of sulfite oxidase, xanthine oxidase, and nitrate reductase. J. Biol. Chem. 255: 1783-1786.

Kaissling, K.-E. (1986) Chemo-electrical transduction in insect olfactory receptors. In Annual Review of Neuroscience, Vol. 9, W. M. Cowan, E. M. Shooter, C. F. Stevens, and R. F. Thompson, eds., pp. 121-145. Annual Reviews, Palo Alto, CA.

Kaissling, K.-E., U. Klein, J. J. de Kramer, T. A. Keil, S. Kanaujia, and J. Hemberger (1985) Insect olfactory cells: Electrophysiological and biochemical studies. In Molecular Basis of Nerve Activity. Proceedings of the International Symposium in Memory of D. Nachmanson, J. P. Changeaux, F. Hucho, A. Maelicke, and E. Neumann, eds., pp. 173-183, W. de Gruyter, Berlin.

Klein, U. (1987) Sensillum-lymph proteins from antennal olfactory hairs of the moth Antheraea polyphemus (Saturnidae). Insect Biochem. 17: 1193-1204.

Laemmli, U. K. (1970) Cleavage of structural proteins during the assembly of the head of bacteriophage T4. Nature 227: 680-685.

Lonergan, G. C. (1986) Metabolism of pheromone components and analogs by cuticular enzymes of Choristoneura fumiferana. J. Chem. Senses 12: 483-496.

Mahler, H. R., B. Mackler, D. E. Green, and R. M. Bock (1954) Studies on metalloflavoproteins III. Aldehyde oxidase: A molybdoflavoprotein. J. Biol. Chem. 210: 465-480.

Matsumoto, S. G., and J. G. Hildebrand (1981), Olfactory mechanisms in the moth Manduca sexta: Response characteristics and morphology of central neurons in the sensillar lobes. Proc. R. Soc. Lond. B 213: 249-277.

Morse, D., and E. Meighen (1984) Detection of pheromone biosynthetic and degradative enzymes in vitro. J. Biol. Chem. 259: 475-480.

O'Farrell, P. H. (1975) High resolution two-dimensional electrophoresis of proteins. J. Biol. Chem. 250: 4007-4021.

Rajagopalan, K. V. (1980) Xanthine oxidase and aldehyde oxidase. In Enzymatic Basis of Detoxication, Vol. 1, W. B. Jakoby, ed., pp. 295-309. Academic, New York.

Rajagopalan, K. V., and P. Handler (1964a) Hepatic aldehyde oxidase II. Differential inhibition of electron transfer to various electron acceptors. J. Biol. Chem. 239: 2022-2026.

Rajagopalan, K. V., and P. Handler (1964b) Hepatic aldehyde oxidase III. The substrate-binding site. J. Biol. Chem. 239: 2027-2035.

Rajagopalan, K. V., I. Fridovich, and P. Handler (1962) Hepatic aldehyde oxidase I. Purification and properties. J. Biol. Chem. 237: 922-928.

Reagan, J. (1987) Chemical investigations of synthesis and olfaction. Ph.D. dissertation, Yale University, New Haven, CT.

Sanes, J. R., and J. G. Hildebrand (1976a) Structure and development of antennae in a moth, Manduca sexta. Develop. Biol. 51: 282-299.

Sanes, J. R., and J. G. Hildebrand (1976b) Origin and morphogenesis of sensory neurons in an insect antenna. Develop. Biol. 51: 300-319.

Schneider, D. (1969) Insect olfaction: Deciphering system for chemical messages. Science 163: 1031-1037.

Schnciderman, A., J. G. Hildebrand, M. M. Brenna, and J. H. Tumlinson (1986) Trans-sexually grafted antennae alter pheromone-directed behavior in a moth. Nature 323: 801-803.

Schweitzer, E. H., J. R. Sanes, and J. G. Hildebrand (1976) Ontogeny of electroantennogram responses in the moth, Manduca sexta. J. Insect Physiol. 22: 955-960.

Segel, I. H. (1976) Biochemical Calculations, pp. 208-319, Wiley, New York.

Starratt, A. N., K. H. Dahm, N. Allen, J. G. Hildebrand, T. L. Payne, and H. Roller (1979) Bombykal, a sex pheromone of the sphinx moth Manduca sexta. Z. Naturforsch. 34c: 9-12.

Steinbrecht, R. A., and W. Gnatzy (1984) Pheromone receptors in Bombyx mori and Antheraea pernyi. I. Reconstruction of the cellular organization of the sensilla trichodea. Cell Tissue Res. 235: 25-34.

Tolbert, L. P., S. G. Matsumoto, and J. G. Hildebrand (1983) Development of synapses in the antennal lobes of the moth Manduca sexta during metamorphosis. J. Neurosci. 3: 1158-1175.

Trapido-Rosenthal, H., W. E. S. Carr, and R. A. Gleeson (1987) Biochemistry of an olfactory purinergic system: Dephosphorylation of excitatory nucleotides and uptake of adenosine. J. Neurochem. 49; 1174-1182.

Visser, J. H., S. Van Straten, and H. Maarse (1979) Isolation and identification of volatiles in the foliage of the potato, Solanum tuberosum, a host plant of the Colorado beetle, Leptinotarsa decemlineata. J. Chem. Ecol. 5: 13-25.

Vogt, R. G. (1987) The molecular basis of pheromone reception: Its influence on behavior. In Pheromone Biochemistry, G. D. Prestwich and G. J. Blomquist, eds., pp. 385-431, Academic, New York.

Vogt, R. G., and L. M. Riddiford (1981a) Pheromone binding and inactivation by moth antennae. Nature 293: 161-163.

Vogt, R. G., and L. M. Riddiford (1981b) Pheromone deactivation by antennal proteins of Lepidoptera. In Regulation of Insect Devel- 
opment and Behavior, F. Sehnal, J. J. Menn, and B. Cymborowski, eds., pp. 955-967, Polytechnical University of Wroclaw Press, Wroclaw, Poland.

Vogt, R. G., L. M. Riddiford, and G. D. Prestwich (1985) Kinetic properties of a sex pheromone-degrading enzyme: The sensillar esterase of Antheraea polyphemus. Proc. Natl. Acad. Sci. ISA 82: 88278831 .
Vogt, R. G., G. D. Prestwich, and L. M. Riddiford (1988) Sex pheromone receptor proteins. J. Biol. Chem. 263: 3952-3959.

Williamson, J. H., M. M. Bentley, M. J. Oliver, and B. W. Geer (1978) The effects of $L A O$ on aldehyde oxidase activity and cross-reacting material in Drosophila melanogaster. Can. J. Genet. Cytol. 20:543553. 